\title{
52. BIOSTRATIGRAPHIC SYNTHESIS OF NEOGENE SILICEOUS MICROFOSSILS FROM THE ANTARCTIC OCEAN, ODP LEG 113 (WEDDELL SEA) ${ }^{1}$
}

\author{
Rainer Gersonde, ${ }^{2}$ Andrea Abelmann, ${ }^{2}$ Lloyd H. Burckle, ${ }^{3}$ Norman Hamilton, ${ }^{4}$ David Lazarus, ${ }^{5}$ Kevin McCartney, ${ }^{6}$ \\ Paul O'Brien, ${ }^{4}$ Volkhard Spieß, ${ }^{7}$ and Sherwood W. Wise, $\mathrm{Jr}^{8}$
}

\begin{abstract}
This paper summarizes the magnetostratigraphic and biostratigraphic results obtained with siliceous microfossils (diatoms, radiolarians, silicoflagellates) on Neogene sections recovered in the Weddell Sea (Antarctic Ocean) during Ocean Drilling Program Leg 113 (Sites 689, 690, 693, 694, 695, 696, and 697). The biostratigraphic studies resulted in the establishment of an improved and revised Neogene biosiliceous zonation for the Antarctic Ocean. The zones are calibrated directly to the geomagnetic time scale. This is the first attempt at direct calibration of Miocene Antarctic biostratigraphic zones with the geomagnetic time scale.
\end{abstract}

\section{INTRODUCTION}

During Ocean Drilling Program (ODP) Leg 113 Neogene sediment sequences were recovered at eight sites, all located in the present-day Antarctic cold-water belt south of the Polar Front. These include pelagic biogenic sediments at Maud Rise (Sites 689 and 690), hemipelagic sequences recovered at the Antarctic continental margin (Sites 691, 692, and 693) and at the eastern South Orkney microcontinent (Sites 695, 696, 697), and a deep-sea turbiditic to hemipelagic sequence in the Weddell Sea abyssal plain (Site 694) (Fig. 1).

Besides objectives concerning the Cenozoic oceanographic and climatic evolution of the southern high-latitudes, one important goal of ODP Leg 113 was to gather well-preserved and continuously recovered Cenozoic sections which allow the establishment of an integrated bio- and magnetostratigraphy for the Antarctic Ocean. This goal was accomplished at some of the sites by drilling with the advanced hydraulic piston corer (APC) or the extended core barrel (XCB) techniques, which prior to Leg 113 never had been used in the area of the present-day Antarctic water mass.

In general the Neogene sediment sequences drilled during Leg 113 contain well to moderately preserved siliceous microfossil assemblages mostly dominated by diatoms. Exceptions are sediments deposited during the latest Pliocene and the middle Pleistocene where the preservation is poor or the sediments are barren in siliceous microfossils (Sites 690, 693, 694, and 697). Another interval with poor preservation or no siliceous microfossils is the expanded lowermost Pliocene of Sites 693, 694, 695,696 , and 697 , which is strongly dominated by terrigenous components.

\footnotetext{
${ }^{1}$ Barker, P. F., Kennett, J. P., et al., 1990. Proc. ODP, Sci. Results, 113: College Station, TX (Ocean Drilling Program).

2 Alfred-Wegener-Institute for Polar and Marine Research, Columbusstraße, D-2850 Bremerhaven, FRG.

${ }^{3}$ Lamont-Doherty Geological Observatory of Columbia University, Palisades, NY 10964.

4 Department of Geology, University of Southampton, Southampton SO9 5 NH, U.K.

5 Geologisches Institut, ETH-Zentrum, CH-8092 Zürich, Switzerland.

6 University of Maine at Presque Isle, Presque Isle, ME 04769.

7 Fachbereich Geowissenschaften, Universität Bremen, Bibliotheksstraße, D2800 Bremen, FRG.

${ }^{8}$ Florida State University, Department of Geology, Tallahassee, FL 32306.
}

The most valuable sections for the improvement of Neogene biostratigraphic zonations based on siliceous microfossils (diatoms, radiolarians, silicoflagellates) are from Holes 689B and 690B drilled on the Maud Rise, despite the relatively low Neogene sedimentation rates ranging between 2.5 and $10.5 \mathrm{~m} / \mathrm{m}$.y. in this area. The combination of the sections recovered at these sites results in a relatively complete Pliocene to early late Miocene APC-cored sequence which allows the first direct correlation of Miocene siliceous microfossil ranges and biostratigraphic zones to geomagnetic stratigraphy. Up to now biostratigraphic zonations tied directly to the geomagnetic polarity time scale were only available for Pliocene and Pleistocene Antarctic sediments (e.g., Hays, 1965; Hays and Opdyke, 1967; McCollum, 1975; Weaver and Gombos, 1981).

The age interpretation for Holes 689B and 690B was based on the geomagnetic polarity pattern in combination with the occurrence and abundance patterns of siliceous microfossil species. The comparison of stratigraphic results gathered at both holes was used to test coherency of the biostratigraphic results and to confirm the absolute age assignment of the species ranges and zonal boundaries. One of the geomagnetic tie-points in the Miocene sequences was the long normal Subchron C $5 \mathrm{~N}-1$ of the middle/late Miocene Chron C5. The established age assignment is supported by the finding that such diatom species as Actinocyclus ingens var. nodus, Denticulopsis hustedtii, D. praedimorpha, and Thalassiosira oestrupii have more or less synchronous first appearance dates (FAD) in the Antarctic Ocean and in the low-latitude and/or high- and mid-latitude North $\mathrm{Pa}$ cific. These FAD's are at ca. $14.9 \mathrm{Ma}(A$. ingens var. nodus $)$, ca. 14.2 Ma (D. hustedtii), ca. $12.6 \mathrm{Ma}$ (D. praedimorpha), and ca. $5 \mathrm{Ma}$ ( $T$. oestrupii).

In contrast to the Maud Rise sites, the Neogene sediment sequences at most of the other sites drilled during Leg 113 (Sites $693,694,695,696$, and 697) were expanded due to higher sedimentation rates. However, the Neogene sequences drilled at these sites were not as useful in establishing improved Neogene stratigraphic zonations, except at Site 695. Most of the Neogene sequences from Site 693 are more or less strongly disturbed, suffered from poor recovery, or were affected by downcore contamination caused by rotary drilling. For this reason a well-established geomagnetic stratigraphy could not be erected for the Neogene of Site 693 . At Site 694 a high recovery rate was only obtained for the topmost sediment sequence representing the latest Neogene, but this interval is almost barren of siliceous mi- 


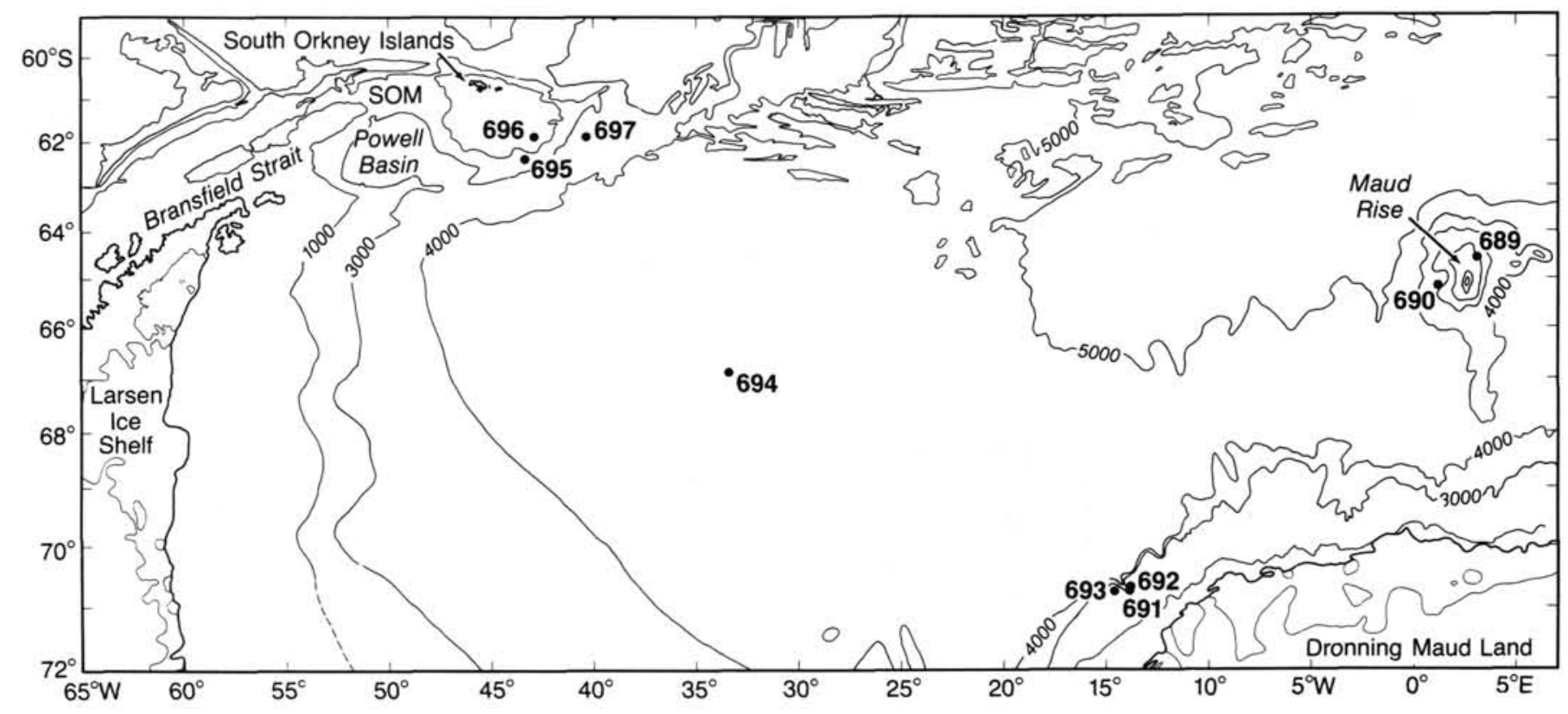

Figure 1. Location of ODP Leg 113 drill sites in the Weddell Sea. Contours in meters, SOM= South Orkney microcontinent.

crofossils. Most of the sampled Miocene sediment sequence at Site 694 only contains moderately to poorly preserved siliceous microfossil assemblages. This plus the poor core recovery precludes a detailed biostratigraphic zonation for Site 694. The latter is also true for the Miocene sediments of Site 696, although preservation is moderate to good. Extremely expanded lower Pliocene sediment sequences were obtained at Sites 695, 696, and 697 (all situated east of the South Orkney Islands) with moderate to good recovery rates. Well-established magnetostratigraphic records exist for Sites 695 and 697 . Especially the record obtained at Site 695 affords a good opportunity for detailed chronostratigraphic calibration of lower Pliocene siliceous microfossil ranges and biostratigraphic zones. At Site 697 wellpreserved siliceous microfossil assemblages are restricted to scattered discrete layers and thus do not allow a continuous and detailed biostratigraphic study.

The stratigraphic interpretation of all Neogene Leg 113 sequences based on the occurrence of diatoms, radiolarians, and silicoflagellates, and available geomagnetic polarity records is summarized in this chapter, except for Sites 691 and 692 that are located in the axis of the Wegener Canyon on Dronning Maud Land margin (Fig. 1). Site 691 was left after three unsuccessful drill attempts that resulted in the recovery of $9 \mathrm{~cm}$ of Quaternary sediment in Hole 691A. Two holes at Site 692, which were drilled close to the position of Site 691 , penetrated a ca. 30-50 mthick Neogene sequence. However, little datable Neogene sediments were recovered. For more details we refer the reader to Barker, Kennett, et al. (1988, Sites 691 and 692 summary).

The Neogene diatom, radiolarian, and silicoflagellate biostratigraphic zonations established for the Leg 113 materials (especially Holes 689B and 690B) and their correlation with the standard geomagnetic time scale are given in Figure 2. The sixteen diatom zones and a number of additional stratigraphically useful diatom datums, which cover a time interval between the middle early Miocene and the Pleistocene, are described by Gersonde and Burckle (this volume, chapter 43). Ten new diatom zones were proposed and six zones established by previous authors (McCollum, 1975; Schrader, 1976; Weaver and Gombos, 1981) were in part modified or renamed. For definition of the zonal boundaries the FAD (first appearance datum) of diatom species was used, except the zones for the late Pliocene and Pleistocene, where only the LAD (last appearance datum) of diatom species was available (Table 1). The use of FAD's for zonal definition avoids problems related to reworking of microfossils by bottom water currents, a widespread phenomenon in Neogene Antarctic sequences.

Lazarus (this volume, chapter 41) presents a refined radiolarian stratigraphy for the late middle Miocene to the Pleistocene, including eight zones, some of them subzoned (Table 2). This study was based on previous zonations of Hays (1965), Chen (1975), Weaver (1976), and Keany (1979). Differences in age interpretation exist between this radiolarian zonation and the diatom zonation of Gersonde and Burckle (this volume, chapter 43) in the middle Pliocene interval and are discussed below.

The radiolarian zonation covering the late Oligocene to middle middle Miocene is established by Abelmann (this volume, chapter 40 ). Ten radiolarian zones were proposed (Table 2), of which six are new and four are modified after Chen (1975).

McCartney and Wise (this volume, chapter 42) used a Neogene silicoflagellate zonation including six zones (Table 3 ) based on previous studies of Bukry (1975) and Ciesielski (1975). However, of the four Miocene zones only the two younger ones were recorded in the investigated Leg 113 material.

Detailed geomagnetic studies were carried out on the Neogene of Holes 689B and 690B (Maud Rise) by Spieß (this volume, chapter 21). The geomagnetic polarity record for Sites 695 and 697 is based on yet unpublished data of Hamilton and O'Brien, who validated the shipboard geomagnetic measurements by shore-based alternating field demagnetization studies. The absolute age assignment is according to the geomagnetic polarity time scale of Berggren et al. (1985). A modified nomenclature proposed by Spieß (this volume, chapter 21), which follows the scheme proposed by Tauxe et al. (1984), is used for designation of geomagnetic events. This nomenclature was also used in the Initial Reports volume of ODP Leg 113 (Barker, Kennett, et al., 1988).

Differences in age interpretation occur in the middle Pliocene time interval between the radiolarian zonation, and the diatom zonation and geomagnetic polarity interpretation. The boundary of the lower Upsilon/middle Upsilon Subzones, which 


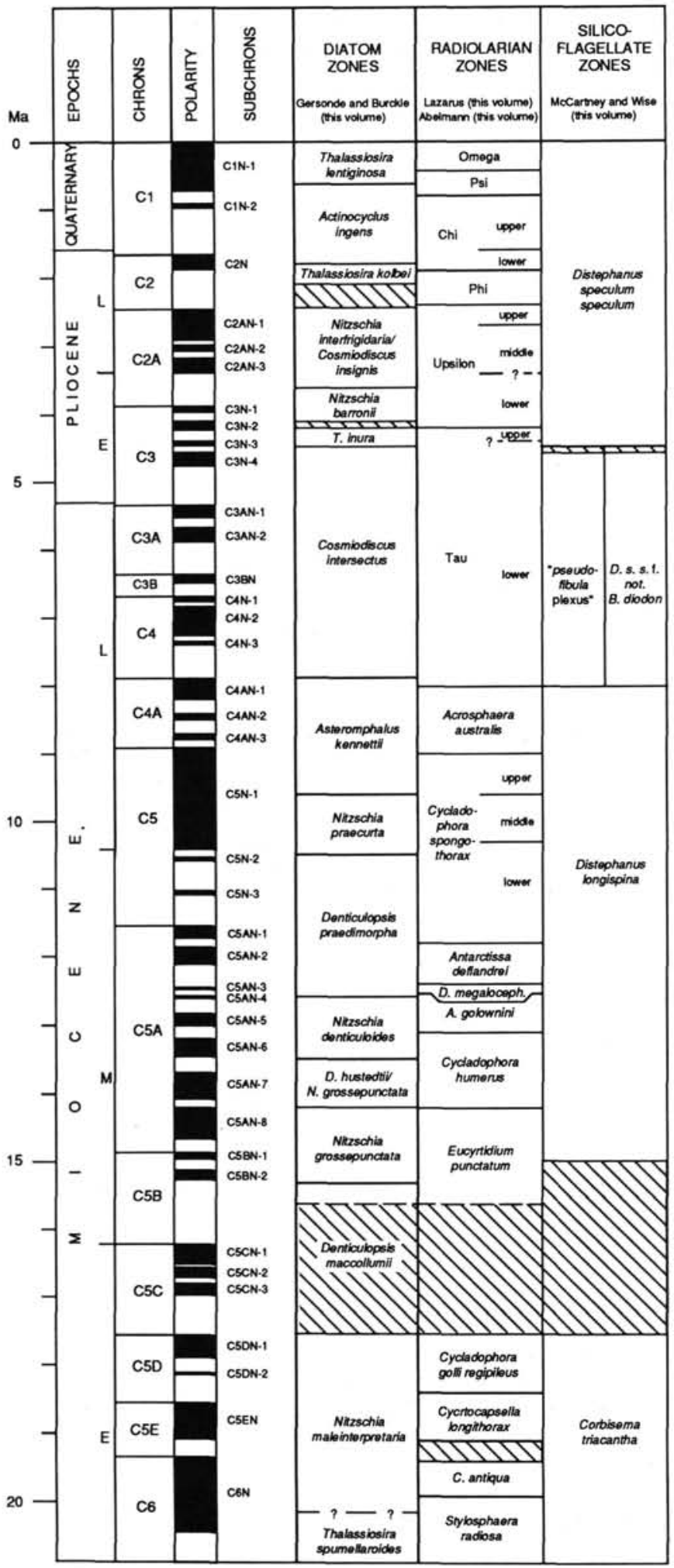

Figure 2. Neogene siliceous microfossil biostratigraphic zonations correlated to the standard geomagnetic time scale. Diatom zonation according to Gersonde and Burckle (this volume, chapter 43 ), radiolarian zonation according to Abelmann (this volume, chapter 40) and Lazarus (this volume, chapter 41), and silicoflagellate zonation according to McCartney and Wise (this volume, chapter 42). The geomagnetic time scale and absolute ages are from Berggren et al. (1985) and the nomenclature of geomagnetic events follows that of Spieß (this volume, chapter 21). Striped boxes indicate the range of uncertain age assignment for zonal boundaries. is defined by the LAD of the radiolarian Prunopyle titan, is placed at ca. 3.4 Ma. A similar age of 3.3 Ma for this datum was tied down on Leg 119 materials (J.-P. Caulet to D. Lazarus, pers. comm., 1989) and sections recovered during Leg 120 (Lazarus, in prep.) in the Indian sector of the Southern Ocean. According to this interpretation the LAD of $P$. titan would be correlated to the lower portion of geomagnetic subchron $\mathrm{C} 2 \mathrm{AN}-3$ that ranges from 3.4 to $3.18 \mathrm{Ma}$ and the Nitzschia interfrigidaria/Cosmiodiscus insignis diatom Zone of Gersonde and Burckle (this volume, chapter 43 ), which has a range between 3.6 and 2.5-2.1 Ma. However, at all holes that contain early Pliocene sequences, the lower/middle Upsilon Subzones boundary was reported in sediment intervals, which were interpreted to correspond to the upper portion of geomagnetic Chron C3 (5.35$3.88 \mathrm{Ma}$ ), and the Nitzschia barronii and Thalassiosira inura diatom Zones that together cover a time interval from 4.47 to $3.6 \mathrm{Ma}$. For this reason the stratigraphic age assignment based on the radiolarian zonation results in younger ages for the middle Pliocene sediment sequences in comparison with the diatom stratigraphy and geomagnetic age interpretation (Figs. 4, 6, 8, $12,14,16)$. The age assignment of the diatom datums that define the Nitzschia barronii and the Thalassiosira inura Zone, e.g., FAD of Nitzschia barronii at 4.2-4.1 Ma and FAD of Nitzschia interfrigidaria at 3.6 Ma (Table 1), was confirmed by Baldauf and Barron (in press) based on Leg 119 material. These dates are also in agreement with the geomagnetic interpretation of the polarity record obtained at Hole $695 \mathrm{~A}$ that represents an expanded and undisturbed C3 Chron (Figs. 11, 12).

Other problematic stratigraphic intervals are around the Miocene/Pliocene boundary, the middle middle Miocene, and below the early middle Miocene. The Miocene/Pliocene boundary in Holes 689B and 690B is marked by a disconformity (Figs. 36 ). This is apparent from the relatively small number of magnetic polarity reversals in these holes in the interval between geomagnetic Subchron $\mathrm{C} 5 \mathrm{~N}-1$ and early Pliocene sediments containing Chron C3. Because of the discontinuous geomagnetic record around the Miocene/Pliocene boundary and the lack of independent biostratigraphic datums calibrated to the absolute time scale for the critical time interval, interpretation of the polarity pattern is problematic. As a prominent tie-point for the interpretation of the late Miocene polarity pattern, the occurrence of Subchron C5N-1 was used. In Hole 690B the inferred hiatus level at 18.8 mbsf corresponds to the boundaries of diatom, radiolarian, and silicoflagellate zones, with in all cases late Miocene zones occurring below the hiatus, and early Pliocene ones above (Figs. 5, 6). The geomagnetic polarity record in Hole 690B between the hiatus at $18.8 \mathrm{mbsf}$ and the top of Chron C5 is thus correlated to the late Miocene, specifically Chron C4A, and it is inferred that the hiatus spans a time interval from ca. 7.9 to $4.6 \mathrm{Ma}$. This hiatus is also marked by changes in physical properties and corresponds to the boundary between geotechnical stratigraphic units G-II and G-III placed at 19 mbsf according to Barker, Kennett, et al. (1988, Site 690).

In Hole 689B, however, the Miocene/Pliocene hiatus is placed by Spieß (this volume, chapter 21), and Gersonde and Burckle (this volume, chapter 43 ) at 17.8 mbsf and falls within diatom, radiolarian, and silicoflagellate zones (Figs. 3,4 ). The geomagnetic polarity pattern between the long normal polarity interval that represents Subchron $\mathrm{C} 5 \mathrm{~N}-1$ and the hiatus at $17.8 \mathrm{mbsf}$ was interpreted to represent Chrons C4A, C4, and C3B, and thus it is inferred that the Miocene/Pliocene hiatus spans from ca. 6.3 to $4.9 \mathrm{Ma}$. This interpretation using $\mathrm{C} 5 \mathrm{~N}-1$ as a tie-point is supported by results obtained on ODP Leg 119 material. Baldauf and Barron (in press) indicate that such diatom species as Actinocyclus ingens var. ovalis, Nitzschia cylindrica, and Thalassiosira miocenica, which in Hole 689B occur below $17.8 \mathrm{mbsf}$ (see Gersonde and Burckle, this volume, chapter 43 ), may be restricted to the latest Miocene in the southern high-latitudes. 


\section{R. GERSONDE ET AL.}

Table 1. Neogene Antarctic diatom zonation, its definition and age range according to Gersonde and Burckle (this volume, chapter 43). Note: FAD = first appearance datum, LAD = last appearance datum, FAAD = first abundant appearance datum ( $>15 \%$ of total diatom assemblage $)$, LAAD = last abundant appearance datum ( $>15 \%$ of total diatom assemblage).

\begin{tabular}{|c|c|c|c|c|}
\hline $\begin{array}{l}\text { Antaretic Diatom Zones } \\
\text { (Gersonde and Burckle, this volume) }\end{array}$ & Ag• Range (Ma) & Dofinition of Base & Definition of Top & Other important Datume \\
\hline Thalassiosira lentiginosa Zone & $0.6 \cdot 0$ & LAD Actinocyclus ingens & Recent & \\
\hline Actinocyclus ingens Zone & ca.1.8 - 0.6 & LAD Thalassiosira kolbei & LAD Actinocyclus ingens & \\
\hline Thalassiosira kolbei Zone & $(2.5-2.1)-$ ca. 1.8 & LAD Cosmiodiscus insignis & LAD Thalassiosira kolbei & \\
\hline $\begin{array}{l}\text { Nitzschia intertrigidaria/Cosmiodiscus } \\
\text { insignis Zone }\end{array}$ & $3.6 \cdot(2.5 \cdot 2.1)$ & FAD Nitzschia intertrigidaria & LAD Cosmiodiscus insignis & \\
\hline Nitzschia barronii Zone & $(4.2-4.1)-3.6$ & FAD Nitzschia barronii & FAD Nitzschia interfrigidaria & \\
\hline Thalassiosira inura Zone & $4.47 \cdot(4.2 \cdot 4.1)$ & FAD Thalassiosira inura & FAD Nitzschia barronii & $\begin{array}{l}\text { 4.3 Ma FAD Rouxia heteropolara } \\
\text { 4.3 Ma FAD Thalassiosira complicata }\end{array}$ \\
\hline Cosmiodiscus intersectus Zone & $7.9 \cdot 4.47$ & FAD Cosmiodiscus intersectus & FAD Thalassiosira inura & $\begin{array}{l}\text { 7.1 Ma LAD Asteromphalus kennettii } \\
\text { ca. 7.3 Ma LAAD Denticulopsis hustedtii } \\
\text { 7.9 - 7.8 Ma FAD A. ingens var. ovalis }\end{array}$ \\
\hline Asteromphalus kennettii Zone & $9.6 \cdot 7.9$ & FAD Asteromphalus kennetti & FAD Cosmiodiscus intersectus & \\
\hline Nitzschia praecurta Zone & $10.5 \cdot 9.6$ & FAD Nitzschia praecurta & FAD Asteromphalus kennetti & $\begin{array}{l}\text { 9.9-9.8 Ma LAAD Denticulopsis dimorpha } \\
\text { 10.4 Ma LAD Denticulopsis praedimorpha }\end{array}$ \\
\hline Denticulopsis praedimorpha Zone & $12.6 \cdot 10.5$ & FAD Denticulopsis praedimorpha & FAD Nitzschia praecurta & $\begin{array}{l}\text { 10.9 -10.8 Ma LAAD D.praedimorpha } \\
11.0 \text { - 10.9 Ma FAAD D. dimorpha } \\
11.5 \text { Ma LAD Nizschia denticuloides } \\
\text { 12.3 Ma LAD A. ingens var, nodus }\end{array}$ \\
\hline Nitzschia denticuloides Zone & $13.5 \cdot 12.6$ & $\begin{array}{l}\text { 1. FAD Nizschia denticuloides } \\
\text { 2. LAD N. grossepunctata }\end{array}$ & FAD Denticulopsis praedimorpha & \\
\hline $\begin{array}{l}\text { Denticulopsis hustedtii/Nitzschia } \\
\text { grossepunctata Zone }\end{array}$ & $14.2 \cdot 13.5$ & FAD Denticulopsis hustedti & $\begin{array}{l}\text { 1. FAD Nitzschia denticuloides } \\
\text { 2. LAD Nitzschia grossepunctata }\end{array}$ & \\
\hline Nitzschia grossepunctata Zone & $15.3 \cdot 14.2$ & FAD Nitzschia grossepunctata & FAD Denticulopsis hustedtii & $\begin{array}{l}\text { 14.4 Ma LAD Denticulopsis maccollumii } \\
\text { 14.9 Ma FAD A. ingens var. nodus } \\
\text { 15.2 Ma FAD Actinocyclus ingens }\end{array}$ \\
\hline Denticulopsis maccollumii Zone & $?(<17.6>15.4) \cdot 15.3$ & FAD Denticulopsis maccollumii & FAD Nitzschia grossepunctata & \\
\hline Nitzschia maleinterpretaria Zone & $? 20.2 \cdot ?(<17.6->15.4)$ & FAD Nitzschia maleinterpretaria & FAD Denticulopsis maccollumii & \\
\hline Thalassiosira spumellaroides Zone & $>? 20.5 \cdot ? 20.2$ & FAD Thalassiosira spumellaroides & FAD Nitzschia maleinterpretaria & ? $19.6 \mathrm{Ma}$ FAD Thalassiosira traga \\
\hline
\end{tabular}

These data also indicate that the silicoflagellate assemblage of Distephanus speculum referred to by McCartney and Wise (this volume, chapter 42) to as "pseudofibula plexus" may have its first occurrence in the latest Miocene, as recorded in Hole 746A. Caulet (pers. comm. to D. Lazarus, 1989) places the LAD of Cycladophora spongothorax, which defines the boundary between Acrosphaera australis and Tau Zone, at ca. $8 \mathrm{Ma}$, a date that also fits well in the age/depth model proposed for Hole 689B (Fig. 4).

Controversial is the interpretation of two distinctly marked middle middle Miocene geomagnetic events in Holes 689B and 690B to represent Subchrons C $5 \mathrm{~N}-3$ and $\mathrm{C} 5 \mathrm{~N}-4$, respectively, as given by Abelmann (this volume, chapter 40 ), and Gersonde and Burckle (this volume, chapter 43). Spieß (this volume, chapter 21 ), who worked out the geomagnetic polarity zonation of both holes, interprets these subchrons to represent Subchrons C5AN-1 and C5AN-2 in Hole 689B, and Subchrons CAN-5 and CAN-6 in Hole 690B. Spieß argues that the short range of both, Sub- chron $\mathrm{C} 5 \mathrm{~N}-3$ and $\mathrm{C} 5 \mathrm{~N}-4$ would not allow a distinctly marked occurrence of the subchrons, considering the general low sedimentation rates during this time interval in both holes. Abelmann and Gersonde and Burckle use the stratigraphic distribution of radiolarians and diatoms by intercalibration of sediment intervals of Holes 689B and 690B for their interpretation of the geomagnetic polarity scheme. Their stratigraphic interpretation is supported by the FAD of the diatom species Denticulopsis praedimorpha (base of the $D$. praedimorpha Zone), which can be placed close to the discussed subzones around 12.6 Ma (Figs. 3, $4)$. The same age for the FAD of $D$. praedimorpha is reported by Barron (1985) for the high- and mid-latitudes of the North Pacific, and is confirmed by Baldauf and Barron (in press) based on Leg 119 material.

More problematic is the age assignment of the lower Miocene sequences in Holes 689B and 690B due to the occurrence of disconformities strongly disturbing the geomagnetic scheme. The stratigraphic interpretation was primarily based on radio- 
Table 2. Neogene Antarctic radiolarian zonation, its definition and age range according to Lazarus (this volume, chapter 41) and Abelmann (this volume, chapter 40). Note: FAD = first appearance datum, LAD = last appearance datum, FCAD = first consistent appearance datum, LAAD = last abundant appearance datum.

\begin{tabular}{|c|c|c|c|c|}
\hline $\begin{array}{l}\text { Antarctic Radiolarian Zones } \\
\text { (Lazarus, this vol., and Abelmann, this vol.) }\end{array}$ & Age Range (Ma) & Definition of Base & Definition of Top & Other important Datums \\
\hline Omegazone & $0.43 \cdot 0$ & LAD Stylatractus universus & Recent & \\
\hline Psi Zone & $0.8 \cdot 0.43$ & $\begin{array}{l}\text { LAD Pterocanium charyodeum } \\
\text { trilobum }\end{array}$ & LAD Stylatractus universus & \\
\hline Chi Zone & $1.9 \cdot 0.8$ & LAD Eucyrtidium calvertense & $\begin{array}{l}\text { LAD Pterocanium charybdeum } \\
\text { trilobum }\end{array}$ & $\begin{array}{l}\text { 1.6 Ma LAD Cycladophora pliocenica } \\
\text { defines boundary of lower/upper subzones }\end{array}$ \\
\hline Phi Zone & $2.4 \cdot 1.9$ & LAD Heloholus verna & LAD Eucyrtidium calvertense & \\
\hline Upsilon Zone & $4.2 \cdot 2.4$ & FAD Helotholus verna & LAD Helotholus verma & $\begin{array}{l}\text { 2.7 Ma FCAD Cyoladophora davisiana } \\
\text { defines boundary of middie/upper subzones } \\
\text { 3.4 Ma LAD Prunopyle titan } \\
\text { defines boundary of lower/middie subzones }\end{array}$ \\
\hline Tau Zone & ca. $8.0 \cdot 4.2$ & LCAD Cycladophora spongothorax & FAD Helotholus verma & $\begin{array}{l}\text { 4.4 Ma LAAD Lychnocanium grande } \\
\text { defines boundary of lower/upper subzones }\end{array}$ \\
\hline Acrosphaera australis Zone & $9.0 \cdot$ ca. 8.0 & FAD Acrosphaera australis & LCAD Cycladophora spongothorax & \\
\hline Cycladophora spongothorax Zone & $11.8 \cdot 9.0$ & FAD Cycladophora spongathorax & FAD Acrosphaera australis & $\begin{array}{l}\text { 9.6 Ma FAD Eucyntidium pseudoinflatum } \\
\text { defines boundary of middie/upper subzones } \\
\text { 10.3 Ma LAD Actinomma golownini } \\
\text { defines boundary of lower/middle subzones }\end{array}$ \\
\hline Antarctissa deflandrei Zone & $12.4 \cdot 11.8$ & LAD Dendrospyris megalocephalis & FAD Cycladophora spongothorax & 12.5 Ma FAD Cornutella clathrata \\
\hline Dendrospyris megalocephalis Zone & $12.55 \cdot 12.4$ & FAD Dendrospyris megalocephalis & LAD Dendrospyris megalocephalis & \\
\hline Actinomma golownini Zone & $13.1-12.55$ & FAD Actinomma golownini & FAD Dendrospyris megalocephalis & \\
\hline Cycladophora humerus Zone & $14.2 \cdot 13.1$ & FAD Cycladophora humerus & FAD Actinomma golownini & 14.2 Ma FAD Lychnocanoma sp. B \\
\hline Evcyrtidium punctatum Zone & $(? 17.6 \cdot 15.4) \cdot 14.2$ & FAD Eucynidium punctatum & FAD Cycladophora humerus & \\
\hline Cycladophora golli regipileus Zone & $18.4 \cdot(717.6 \cdot 15.4)$ & FAD Cycladophora golli regipileus & FAD Eucyridium punctatum & $\begin{array}{l}\text { 18.4 Ma FAD Stauroxiphos communis } \\
\text { 18.4 Ma FAD Gondwanaria deflandrei }\end{array}$ \\
\hline Cyrtocapsella longithorax Zone & $(19.4 \cdot 19.1) \cdot 18.4$ & FAD Cyrtocapsella longithorax & FAD Cydadophora golli regipileus & 19.4-19.1 Ma FAD Dendrospyris stabilis \\
\hline Cycladophora antiqua Zone & ca. $19.9 \cdot(19.4 \cdot 19.1)$ & FAD Cycladophora antiqua & FAD Cynocapsella longithorax & $\begin{array}{l}\text { ca. 19.9 Ma FAD Velicucullus altus } \\
\text { ca. 19.9 Ma LAD Stylosphaera radiosa } \\
\text { ca. 19.9 Ma LAD Lychnocanoma conica }\end{array}$ \\
\hline Stylosphaera radiosa Zone & ?27.7 - ca. 19.9 & FAD Stylosphaera radiosa & FAD Cycladophora antiqua & \\
\hline Cyrocapsella robusta Zone & ?27.7 - 227.2 & FAD Cynocapsella robusta & FAD Stylosphaera radiosa & . \\
\hline
\end{tabular}

larian biostratigraphic results of Abelmann (this volume, chapter 40 ). Her results rely on a comparison of radiolarian biostratigraphic data of Holes 689B and 690B with yet unpublished data of Leg 120 holes (Abelmann, in prep.).

Zonal boundary ages and ages of species ranges were calculated assuming constant sedimentation rates between the various geomagnetic and biostratigraphic data points. The sub-bottom depth (mbsf) of zonal boundaries and disconformities was calculated as the midpoint between sub-bottom depths of studied samples below and above these events or boundaries. For more detailed stratigraphic reports and definition of the Neogene biostratigraphic zones, the reader is referred to the individual biostratigraphic and paleomagnetic chapters.

\section{SITE 689}

Site $689\left(64^{\circ} 31.01^{\prime} \mathrm{S}, 3^{\circ} 6.00^{\prime} \mathrm{E}\right)$ is located near the crest of Maud Rise in $2080 \mathrm{~m}$ of water (Fig. 1). This site was chosen to obtain a high-quality (APC-XCB) cored pelagic biogenic sequence of Upper Cretaceous to Cenozoic sediments to investigate in detail the paleoceanographic history of the Antarctic Ocean based on the microfossil and stable isotope record and to improve the Cenozoic biostratigraphic framework for the southern high-latitudes. Four holes were drilled at Site 689. Of these, Hole 689B, which fully recovered a 67-m-thick Neogene sequence, except for some minor gaps, was studied in detail, and an integrated bio- and magnetostratigraphy was established (Fig. 3). 
Table 3. Neogene Antarctic silicoflagellate zonation, its definition and age range according to McCartney and Wise (this volume, chapter 42). Note: FAD = first appearance datum, LAD = last appearance datum.



However, none of the holes drilled at Site 689 obtained the mud line or recovered undisturbed topmost sediments. Drilling disturbances were possibly also caused by the presence of an ?upper Pliocene chert layer. The sediments at the top of Hole 689B were dated as late early Pliocene to ?early late Pliocene in age. Scattered admixtures of Pleistocene diatom species indicate downhole contamination in the topmost $15 \mathrm{~m}$ of Hole 689B. A 6.8-mlong piston core (PS 1585-3) taken during Polarstern cruise ANT V1/3 close to Site 689 at $64^{\circ} 31^{\prime} \mathrm{S}$ and $3^{\circ} 5^{\prime} \mathrm{E}$ (water depth $2075 \mathrm{~m}$ ) recovered a 3.4-m-thick foraminiferal ooze of Quaternary age underlain by Pliocene diatomaceous ooze. The base of the piston core penetrated into the early/late Pliocene Nitzschia interfrigidaria/Cosmiodiscus insignis Zone.

In general, the Neogene sediments of Hole 689B contain moderately to well preserved siliceous microfossil assemblages dominated by diatoms. The Pliocene and upper Miocene sediments are radiolarian bearing and radiolarian diatom oozes, respectively. The early Pliocene is characterized by the occurrence of silicoflagellate ooze dominated by Distephanus speculum and $D$. boliviensis and below that, by an interesting assemblage of $D$. speculum that lacks apical rings and is referred to as the "pseudofibula plexus" (McCartney and Wise, this volume, chapter 42). The average sedimentation rate of the early Pliocene interval is ca. $10.5 \mathrm{~m} / \mathrm{m}$. y. (Fig. 4, Table 4), thus representing the highest values in the Neogene at Site 689. The Pliocene and Miocene sediments are separated at $17.8 \mathrm{~m}$ by a hiatus spanning ca. 6.3-4.9 Ma, according to Gersonde and Burckle (this volume, chapter 43) and Spieß (this volume, chapter 21) (for discussion see "Introduction" section, this chapter. Sedimentation rates during the late Miocene were estimated to be on average $7 \mathrm{~m} / \mathrm{m} . \mathrm{y}$.

The boundary between the middle and late Miocene can be placed around $35 \mathrm{mbsf}$. The exact position of this boundary is not clear because the lower boundary of Subchron C $5 \mathrm{~N}-1$ is not well defined due to drilling disturbances. The middle and lower Miocene sediments are represented by a wide variety of pure and mixed biogenic siliceous and biogenic calcareous sediment types. The sedimentation rates are lower compared to the late Miocene and are on average $6.5 \mathrm{~m} / \mathrm{m}$.y. and $2.5 \mathrm{~m} / \mathrm{m}$.y. for the middle and early Miocene, respectively (Fig. 4, Table 4). A distinct calcareous interval with diatom-bearing nannofossil ooze occurs in the upper portion of the middle Miocene and is more or less well correlated with acmes of the diatom species Denticulopsis dimorpha and D. praedimorpha (see Gersonde and Burckle, this volume, chapter 43). A number of hiatuses were determined in the middle and lower Miocene sediment sequences based on combined diatom, radiolarian, and magnetostratigraphic results. One of them, placed at ca. $58.8 \mathrm{mbsf}$, separates the lower and middle Miocene sediment sequences and probably spans from 17.6 to $15.6 \mathrm{Ma}$. Hiatuses occurring within the early Miocene sediments strongly disturb the geomagnetic scheme and impede accurate age assignment of the sediment sequences. However, the radiolarian data of Abelmann (this volume, chapter 40), which also consider stratigraphic results of Leg 120 sites, allow a tentative age assignment for the lower Miocene sequences. Based on this interpretation, a hiatus spanning from ca. 26.3 to 20.0 Ma separates the Oligocene and Miocene sediments. This hiatus was placed between Sample 113-689B-8H-4, 28-29 cm, and Sample 113-689B-8H-3, 144-145 cm (67.0 mbsf).

\section{SITE 690}

Site 690 , situated on the southwestern flank of Maud Rise $\left(65^{\circ} 9.6^{\prime} \mathrm{S}, 1^{\circ} 12.3^{\prime} \mathrm{E}\right.$; water depth $\left.2914 \mathrm{~m}\right)$, is the deeper of two sites on the rise that form part of a depth transect for studies of vertical-water-mass stratification and biogenic sedimentation in the Weddell Sea during the Cenozoic (Fig. 1). The scientific objectives are similar to those at Site 689 . Three holes were drilled at Site 690. Of these, Hole 690B, which fully recovered (APC drilling technique) a 51.2-m-thick Neogene sequence was studied in detail. By comparison with Hole 689B, an integrated bioand magnetostratigraphy was established (Fig. 5). The lithology and microfossil content of Hole 690B are similar to those in Hole 689B. However, in contrast to Hole 689B the Neogene sedimentation rates are slightly lower in the Miocene (Fig. 6, Table $4)$, and the section is affected by more hiatuses. The most important hiatuses are at ca. 18.8 and 51.2 mbsf. The latter spans from ca. 27 to $20.5 \mathrm{Ma}$ and separates upper Oligocene and lower Miocene sediments. The hiatus at ca. $18.8 \mathrm{mbsf}$ covers approximately the interval 7.9-4.6 Ma, thus upper Miocene and lowermost Pliocene sediments are missing.

In contrast to Hole 689B the mud line was recovered in Hole 690B along with Quaternary sediments consisting of a ca. 3-mthick foraminiferal ooze. In this interval the preservation of siliceous microfossils is in general moderate to poor. The lower Pliocene sediments contain an ooze consisting of the giant diatom species Ethmodiscus rex. This abundance interval was placed between Sample 113-690B-2H-6, 114-115 cm, and Sample 113690B-2H-5, 28-29 cm and was dated at about 3.8-3.9 Ma (within the Nitzschia barronii Zone). Such an ooze that has also been reported from piston cores from the Maud Rise and the 


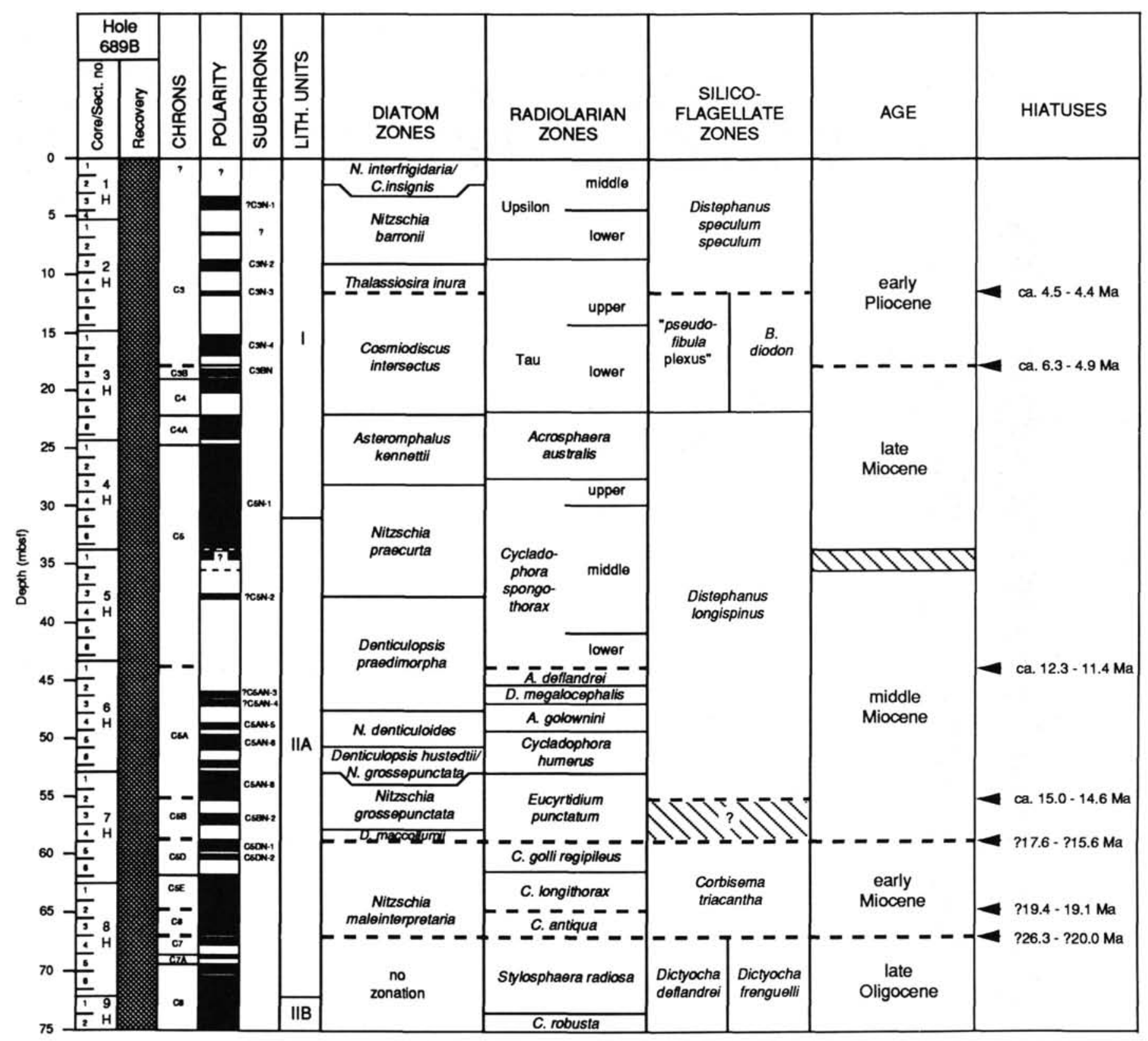

Figure 3. Summary of Neogene siliceous microfossil biostratigraphy correlated to the geomagnetic polarity pattern, Hole 689B (Maud Rise), and age range of disconformities according to Gersonde and Burckle (this volume, chapter 43). Geomagnetic stratigraphy according to Spieß (this volume, chapter 21). Horizontal dashed line indicates placement of hiatus (only indicated where zonal boundaries are marked by a hiatus), striped boxes indicate range of uncertain age assignment for zonal boundaries. Explanation of lithologic units: $\mathrm{I}=$ radiolarian-bearing and radiolarian diatom ooze, and silicoflagellate diatom ooze, IIA = diatom and nannofossil ooze, IIB = nannofossil ooze and diatom-bearing nannofossil ooze.

Weddell basin (Abelmann et al., in press) could not be found in Hole 689B, probably because of drilling disturbances.

\section{SITE 693}

Site 693 is located on a midslope bench on the Weddell Sea margin of East Antarctica $\left(70^{\circ} 49.9^{\prime} \mathrm{S}, 14^{\circ} 34.4^{\prime} \mathrm{W}\right), 10 \mathrm{~km}$ southwest of the rim of Wegener Canyon, in $2359 \mathrm{~m}$ of water (Fig. 1). The site was planned to examine the Cenozoic record of Antarctic continental cooling and ice-sheet formation. Two holes were drilled at Site 693. Hole 693A sampled a ca. 300-310-mthick Neogene sediment sequence. Because of rotary drilling this sequence is not well recovered, and the cores are affected by drilling disturbances and downhole contamination (see "Physi- cal Properties" section in Barker, Kennett, et al., 1988, Site 693). A well-established magnetic stratigraphy could not be worked out for this hole. The same is true for Hole 693B, which was washed down to upper Miocene sediments at 234 mbsf and continued by use of the XCB coring system.

In general siliceous microfossils occur throughout the Neogene sequences of Site 693 and allow a biostratigraphic age assignment for the recovered sequences (Fig. 7). Within the Pleistocene, the preservation of siliceous microfossil assemblages is variable and ranges from poor to well preserved. The upper Pliocene sections are mostly barren and are underlain by an expanded lower Pliocene sequence consisting of diatom clayey or diatom silty mud. Here the average sedimentation rates increase 


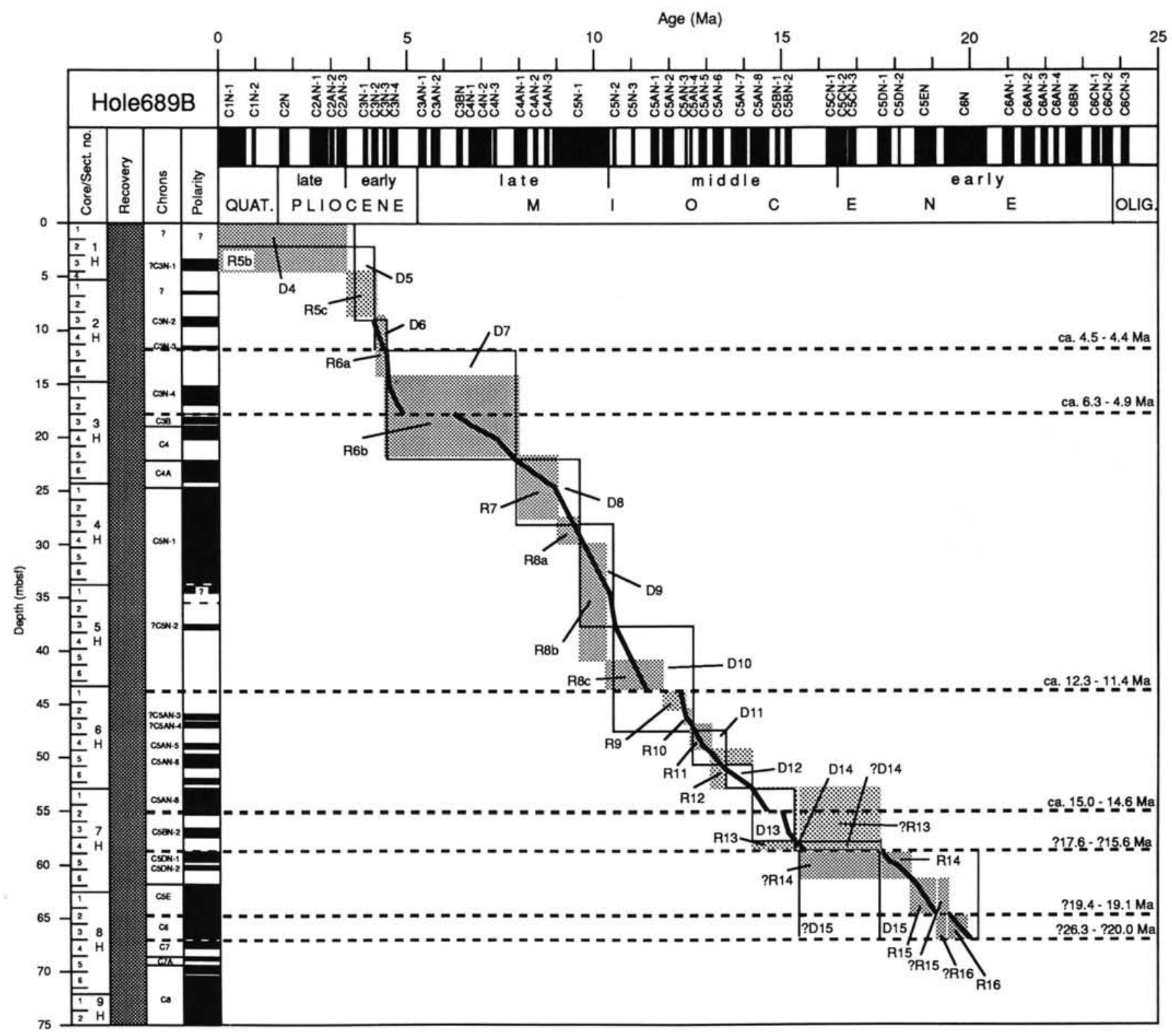

Figure 4. Age-depth interpretation of Hole 689B based on the geomagnetic polarity pattern (thick line) and biosiliceous zonations. Boxes indicate depth/age range of radiolarian (R) zones (stippled boxes) and diatom (D) zones (open boxes). Horizontal dashed lines indicate location of hiatuses. Explanation of diatom zonal numbers: D4. Nitzschia interfrigidaria/Cosmiodiscus insignis Zone; D5. Nitzschia barronii Zone; D6. Thalassiosira inura Zone; D7. Cosmiodiscus intersectus Zone; D8. Asteromphalus kennettii Zone; D9. Nitzschia praecurta Zone; D10. Denticulopsis praedimorpha Zone; D11. Nitzschia denticuloides Zone; D12. Denticulopsis hustedtii/Nitzschia grossepunctata Zone; D13. Nitzschia grossepunctata Zone; D14. Denticulopsis maccollumii Zone; D15. Nitzschia maleinterpretaria Zone. Radiolarian zonal numbers: R5b. middle Upsilon Zone; R5c. lower Upsilon Zone; R6a. upper Tau Zone; R6b. lower Tau Zone; R7. Acrosphaera australis Zone; R8a. upper Cycladophora spongothorax Zone, R8b. middle C. spongothorax Zone, R8c. lower C. spongothorax Zone; R9. Antarctissa deflandrei Zone; R10. Dendrosphyris megalocephalis Zone; R11. Actinomma golownini Zone; R12. Cycladophora humerus Zone; R13. Eucyrtidium punctatum Zone; R14. Cycladophora golli regipileus Zone; R15. Cyrtocapsella longithorax Zone; R16. Cycladophora antiqua Zone. For zonal definition see Tables 1 and 2.

to $60 \mathrm{~m} / \mathrm{m} . \mathrm{y}$, while the Pleistocene values are ca. $16 \mathrm{~m} / \mathrm{m} . \mathrm{y}$. on average (Fig. 8, Table 4). Poor preservation and barren intervals occur near the Miocene/Pliocene boundary and in the upper Miocene. The location of the Miocene/Pliocene boundary is uncertain. The boundary can tentatively be placed between Sections 113-693A-18R, CC, and 113-693A-14R, CC, which corresponds to 166.6-127.8 mbsf. Because of the poor recovery and the lack of well-preserved biostratigraphic marker species it cannot be determined if the Miocene/Pliocene boundary is marked by a hiatus. The laboratory-measured and the continuous-logging-determined profiles of physical properties do not indicate distinct changes that could be interpreted to represent a disconformity in the interval between 170 and 120 mbsf (Barker, Kennett, et al., 1988, Site 693).

Moderately preserved assemblages were recorded from sediment intervals placed around the late/middle Miocene boundary (Nitzschia praecurta and Denticulopsis praedimorpha Zones, and Cycladophora spongothorax Zone). Here average sedimen- 


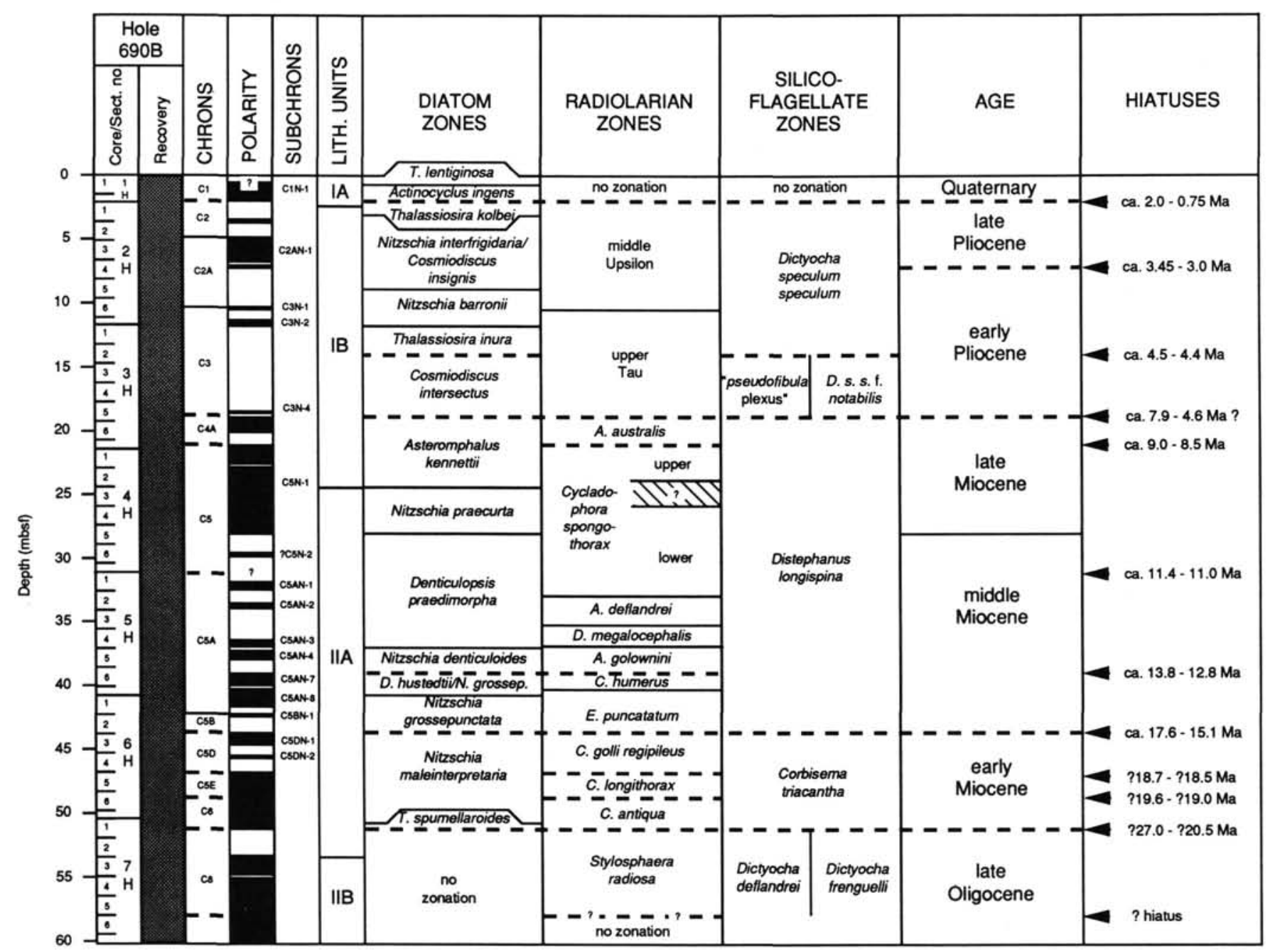

Figure 5. Summary of Neogene siliceous microfossil biostratigraphy correlated to the geomagnetic polarity pattern, Hole 690B (Maud Rise), and age range of disconformities according to Gersonde and Burckle (this volume, chapter 43). Geomagnetic stratigraphy according to Spieß (this volume, chapter 21). Horizontal dashed line indicates placement of hiatus (only indicated where zonal boundaries are marked by a hiatus), striped boxes indicate range of uncertain age assignment for zonal boundaries. Explanation of lithologic units: IA = foraminiferal ooze, IB = diatom ooze, IIA = diatom-bearing nannofossil ooze, IIB = nannofossil ooze with diatom-rich layers.

tation rates are ca. $24 \mathrm{~m} / \mathrm{m}$.y. Most of the middle Miocene and some upper lower Miocene is omitted at a disconformity, which lies between Section 113-693A-28R, CC, and Sample 113-693A$29 \mathrm{R}-1,20-21 \mathrm{~cm}$ (ca. $263 \mathrm{mbsf}$ ) and spans roughly from 15 to $11 \mathrm{Ma}$ (Fig. 8). This hiatus is also marked by a complex log signal and represents a strong seismic reflector (Barker, Kennett, et al., 1988, Site 693). Below the hiatus, siliceous microfossil preservation is moderate to poor, and successively deteriorates with increasing depth. For this reason the placement of the Miocene/ Oligocene boundary at Site 693 can only be estimated based on silicoflagellate and radiolarian data. The latest Oligocene silicoflagellates attributed to the Dictyocha frenguelli Zone were recorded at Sample 113-693A-33R-1, 96-98 cm (ca. $302.5 \mathrm{mbsf}$ ), while the first unquestionable Miocene radiolarians were reported from Section 113-693B-8X, CC (ca. 292 mbsf).

\section{SITE 694}

Site 694 is in the northern part of the Weddell Sea abyssal plain $\left(66^{\circ} 50.8^{\prime} \mathrm{S}, 33^{\circ} 26.8^{\prime} \mathrm{W}\right)$ in a water depth of $4653 \mathrm{~m}$ (Fig. 1). The site is the deepest of the seven sites that form a transect across the Weddell Sea region. It was drilled to provide a record of continental erosion during glacial and preglacial time periods, which would allow an insight into climatic changes on the Antarctic continent. The site was also drilled to provide data related to bottom-water production in the Weddell Sea.

Four holes were drilled at Site 694 . Hole $694 \mathrm{~A}$ was abandoned after recovery of the first core because the sediment/water interface was not sampled. The base of this 9.8-m-long core is in a sediment interval rich in siliceous microfossils which can be assigned to the late early Pliocene Nitzschia barronii diatom Zone, or the lower Upsilon radiolarian Zone. In Hole 694B the latter interval was recovered at around 13 mbsf (Fig. 9).

The recovery in Hole 694B, which was abandoned in upper Miocene sediments at 179 mbsf, was continuous only in the topmost three cores. Below the third core recovery dropped considerably because of the occurrence of medium- to coarse-grained sands, between ca. 21 and 111.5 mbsf (Cores 113-694B-5H to $-14 \mathrm{H})$. All Pliocene and Pleistocene sediments above this sandy interval were barren in siliceous microfossils except for the diatomaceous interval described above at around $13 \mathrm{mbsf}$. Average sedimentation rates are ca. $3 \mathrm{~m} / \mathrm{m}$.y. in the Quaternary and late Pliocene, according to preliminary geomagnetic polarity inter- 


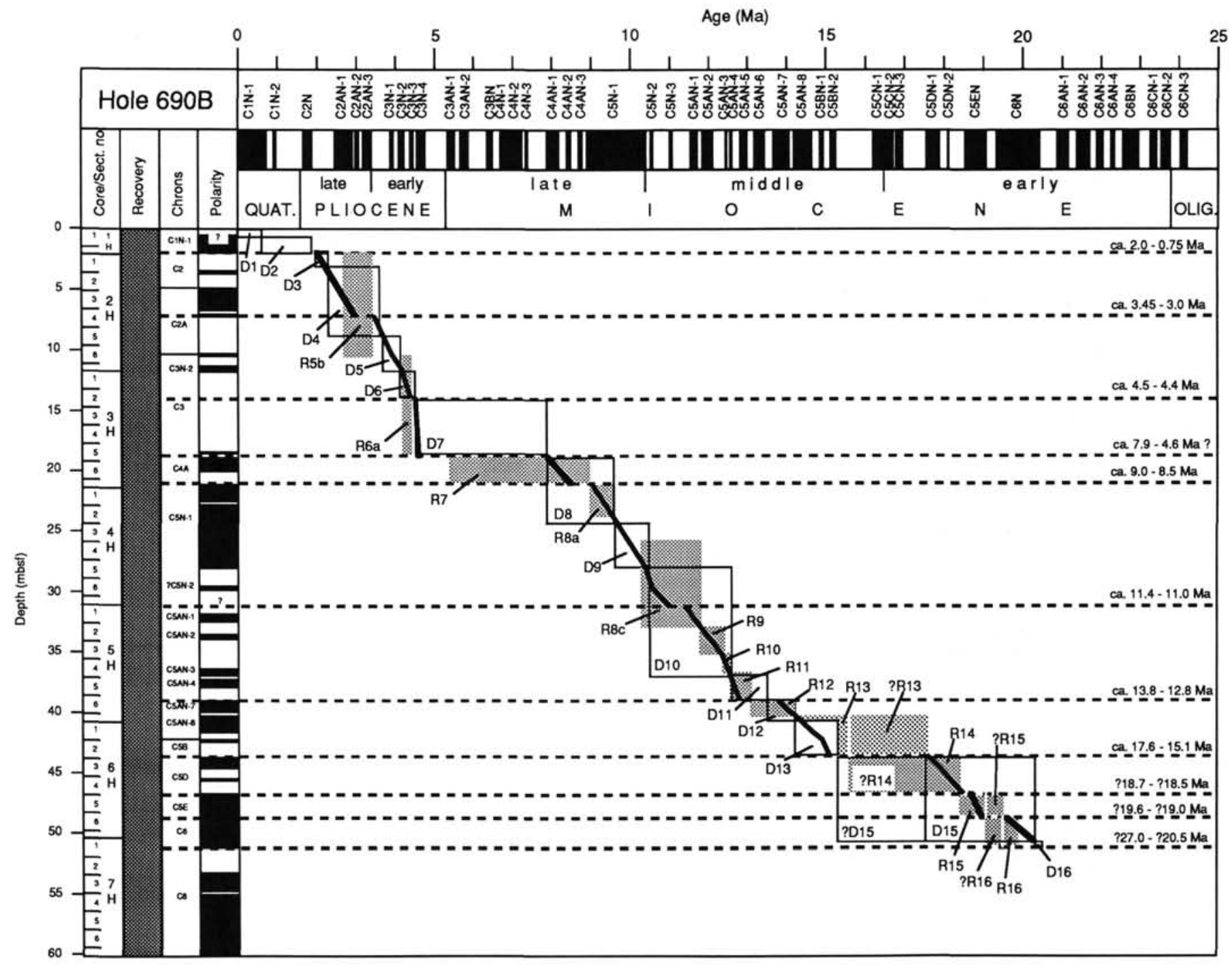

Figure 6. Age-depth interpretation of Hole 690B based on the geomagnetic polarity pattern (thick line) and biosiliceous zonations. Boxes indicate depth/age range of radiolarian (R) zones (stippled boxes) and diatom (D) zones (open boxes). Horizontal dashed lines indicate location of hiatuses. Explanation of diatom zonal numbers: D1. Thalassiosira lentiginosa Zone; D2. Actinocyclus ingens Zone; D3. Thalassiosira kolbei Zone; D4. Nitzschia interfrigidaria/Cosmiodiscus insignis Zone; D5. Nitzschia barronii Zone; D6. Thalassiosira inura Zone; D7. Cosmiodiscus intersectus Zone; D8. Asteromphalus kennettii Zone; D9. Nitzschia praecurta Zone; D10. Denticulopsis praedimorpha Zone; D11. Nitzschia denticuloides Zone; D12. Denticulopsis hustedtii/Nitzschia grossepunctata Zone; D13. Nitzschia grossepunctata Zone; D15. Nitzschia maleinterpretaria Zone; D16. Thalassiosira spumellaroides Zone. Radiolarian zonal numbers: R5b. middle Upsilon Zone; R6a. upper Tau Zone; R7. Acrosphaera australis Zone; R8a. upper Cycladophora spongothorax Zone; R8c. lower C. spongothorax Zone; R9. Antarctissa deflandrei Zone; R10. Dendrospyris megalocephalis Zone; R11. Actinomma golownini Zone; R12. Cycladophora humerus Zone; R13. Eucyritidium punctatum Zone; R14. Cycladophora golli regipileus Zone; R15. Cyrtocapsella longithorax Zone; R16. Cycladophora antiqua Zone. For zonal definition see Tables 1 and 2.

pretations (Barker, Kennett, et al., 1988, Site 694). Below the sandy interval sediments bearing moderately preserved siliceous microfossils were recovered in Core $14 \mathrm{H}$. The composition of the siliceous microfossil assemblages indicates an age near the Miocene/Pliocene boundary. Above that level the sedimentation rates are estimated to range between 25 and $120 \mathrm{~m} / \mathrm{m}$.y. (Fig. 10, Table 4). Below that level most samples are barren of siliceous microfossils or contain only poorly preserved assemblages. In Core 113-694B-24X, the diatom Denticulopsis dimorpha is common to abundant. At the sites drilled on Maud Rise a D. dimorpha acme was observed around the middle/upper Miocene boundary (upper Denticulopsis dimorpha to Nitzschia praecurta Zone) between ca. 11.0 and 9.8 Ma. An abundant, well-preserved upper Cycladophora spongothorax Zone radiolarian as- semblage from Section 113-694B-24X, CC, gives a slightly younger age of ca. 9.6-9.0 Ma. Average sedimentation rates in the late Miocene estimated based on the scattered occurrence of datable sediment intervals are ca. $24 \mathrm{~m} / \mathrm{m}$.y., thus comparable with those of Site 693 (Table 4).

Hole $694 \mathrm{C}$ was washed down to the total depth of Hole 694B and continued at this depth with XCB drilling. The recovery of Hole $694 \mathrm{C}$, which reached $391 \mathrm{mbsf}$, was low. Major sediment types are sandy and silty muds bearing poorly to moderately preserved diatoms. Low recovery and poor preservation of siliceous microfossils did not allow an accurate biostratigraphic age assignment for the recovered sequences. Most of the sediments drilled in Hole $694 \mathrm{C}$ can be placed in the middle Miocene, based on scattered occurrences of diatom and radiolarian 
Table 4. Average sedimentation rates at Leg 113 sites in meters per million years $(\mathrm{m} / \mathrm{m} . \mathbf{y}$.).

\begin{tabular}{|l|c|c|c|c|c|c|c|}
\hline & $689 \mathrm{~B}$ & $690 \mathrm{~B}$ & $693 \mathrm{~A}, \mathrm{~B}$ & $694 \mathrm{~B}, \mathrm{C}$ & $\mathbf{6 9 5} \mathrm{A}$ & $696 \mathrm{~A}, \mathrm{~B}$ & $697 \mathrm{~A}, \mathrm{~B}$ \\
\hline Quaternary & - & $?$ & 16 & 3 & 3.5 & 4 & 28 \\
late Pliocene & $?$ & 5 & $?$ & 3 & 35 & 4 & 28 \\
early Pliocene & 10.5 & 10.5 & 60 & $25-120$ & $170-250$ & 140 & 100 \\
late Miocene & 7 & 5 & 24 & 24 & - & 35 & - \\
middle Miocene & 6.5 & 4.5 & $?$ & 70 & - & 120 & - \\
early Miocene & 2.5 & 2.5 & $?$ & - & - & - & - \\
\hline
\end{tabular}

biostratigraphic marker species. An average sedimentation rate of $70 \mathrm{~m} / \mathrm{m}$.y. was estimated (Fig. 10). Altogether, the dating of Neogene sediment sequences recovered at Site 694 is the least accurate of all sites drilled during Leg 113, except those sampled at Sites 691 and 692.

\section{SITE 695}

Site 695 is located on the southeast margin of the South Orkney microcontinent $(\mathrm{SOM})$ in the northeast Weddell Sea $\left(62^{\circ} 23.5^{\prime} \mathrm{S}\right.$, $43^{\circ} 27.1^{\prime} \mathrm{W}$ ) at $1300 \mathrm{~m}$ water depth (Fig. 1). Site 695 is the intermediate of three sites $(695,696,697)$ in a depth transect on the northern margin of the present-day Weddell Gyre. These were drilled to study the Neogene development of Antarctic water masses. One hole was drilled at this site using the APC and $\mathrm{XCB}$ coring techniques, and a 341-m-thick Quaternary to upper Miocene sequence was sampled consisting of predominantly diatom silty and clayey mud. Preservation of siliceous microfossil assemblages is in general moderate to good, except in the lowermost portion of the hole (below Core 113-695A-36X) where the preservation is poor. Core recovery and condition range from good to moderate, allowing dense and more or less continuous sampling for biostratigraphic and magnetostratigraphic studies (Fig. 11).

At Site 695 the Pleistocene and uppermost Pliocene are highly condensed. On average not more than $3.5 \mathrm{~m}$ of sediment was deposited during this time interval per 1 million years (Fig. 12, Table 4). The Quaternary sequence at the top of Lithostratigraphic Subunit 1A is a ca. 2-m-thick foraminifer-bearing clayey mud. Preservation of siliceous microfossils in this sediment sequence is generally poor. In the underlying upper Pliocene the siliceous microfossils exhibit a marked increase in diversity and preservation. The sedimentation rate increases gradually from the upper Pliocene, where they are at about $35 \mathrm{~m} / \mathrm{m}$.y., to the lower Pliocene. A dramatic increase in the sedimentation rate occurs in the early Pliocene, so that the lower Pliocene biostratigraphic zones, which in general are short ranging, are drastically expanded. Here the average sedimentation rate is ca. $170-250 \mathrm{~m}$ per m.y., and represents the highest sedimentation rate of all Neogene sections drilled during Leg 113 (Fig. 12, Table 4).

Based on logs of physical properties, a hiatus or the very rapid onset of diagenetic cementation is suggested at $315 \mathrm{mbsf}$ (top of geotechnical unit G10, see Barker, Kennett, et al.,1988, Site 695 ), also indicated by a seismic reflector. The occurrence of the Acrosphaera australis Zone, which ranges between 9 and $8 \mathrm{Ma}$, at the base of Hole 695A supports the presence of a Miocene/Pliocene hiatus. Considering the range of the co-occurring Cosmiodiscus intersectus Zone and the pattern of the lower Pli- ocene age/depth curve it can be estimated that this hiatus ranges from ca. $8 \mathrm{Ma}$ to ca. $5 \mathrm{Ma}$, and that the hole terminated in the middle portion of the late Miocene. However, this age assignment is tentative because of the poor preservation of siliceous microfossils in the four lowermost cores of Hole 695A.

Hole 695A is useful for the improvement of Pliocene siliceous microfossil biostratigraphy because it provides a well-recovered and extremely expanded lower Pliocene section. The well-established magnetostratigraphic record affords a good opportunity for detailed chronostratigraphic calibration of the siliceous microfossil ranges and biostratigraphic zones. Up to now the biostratigraphic studies rely only on the investigation of core catcher samples, but further work is in progress to refine the biostratigraphic data base at Hole 695A.

\section{SITE 696}

Site 696 lies on the southeast margin of the South Orkney microcontinent (SOM), in $650 \mathrm{~m}$ of water at $61^{\circ} 50.9^{\prime} \mathrm{S}, 42^{\circ} 56^{\prime} \mathrm{W}$ (Fig. 1). Site 696 is the shallowest Leg 113 site in the Weddell Sea depth transect. It was drilled to recover a carbonate record, especially for the Oligocene through middle Neogene, and to study the history of the circumpolar deep water and the glacial history of the Antarctic Peninsula. Two holes were drilled at Site 696. Hole 696A, which has its base in middle lower Pliocene sediments at 103 mbsf, includes 10 APC and 2 XCB cores. Hole 696B was washed to 76.6 mbsf and continued by rotary drilling. Deepest datable Neogene sediments were sampled in Core 113696B-50R, at ca. $530 \mathrm{mbsf}$, and placed in the lower middle Miocene Nitzschia grossepunctata Zone (Fig. 13). Recovery of the sedimentary sequence was in general poor. Geomagnetic measurements were made on the lower Pliocene sequences, but the identification of the obtained polarity pattern is equivocal (see Barker, Kennett, et al., 1988, Site 696).

As at Site 695, the Pleistocene and uppermost Pliocene at Site 696 are strongly condensed resulting in a sedimentation rate of ca. $4 \mathrm{~m} / \mathrm{m}$.y. Sediments of the early Pliocene Nitzschia barronii and early/late Pliocene Nitzschia interfrigidaria/Cosmiodiscus insignis diatom Zones, highly expanded at Site 695, are missing due to a hiatus or are condensed. The recovered middle to lowermost Pliocene sediment sequences are strongly expanded due to high rates of biosiliceous accumulation during the deposition of the middle early Pliocene and due to high rates of terrigenous accumulation during the lowermost Pliocene. The average sedimentation rate is ca. $140 \mathrm{~m} / \mathrm{m}$.y. (Fig. 14, Table 4). The sediment interval expected to include the Miocene/Pliocene boundary was not recovered. Based on the biostratigraphic data and the inferred age/depth curve, the Miocene/Pliocene bound- 


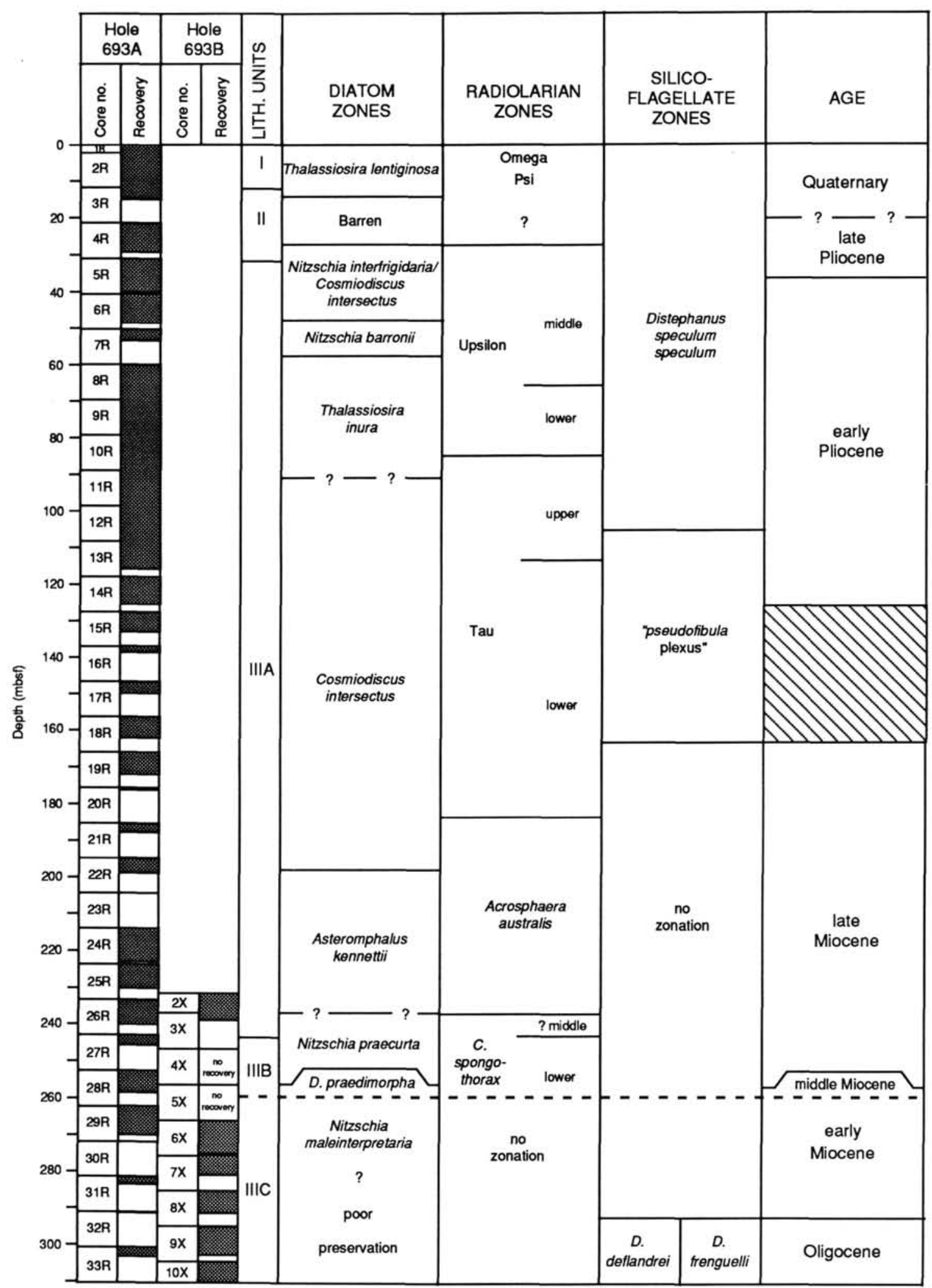

Figure 7. Summary of Neogene siliceous microfossil biostratigraphy, Holes 693A, B (Antarctic continental margin). Thick dashed line indicates placement of hiatus, striped boxes indicate range of uncertain age assignment for zonal boundaries. Explanation of lithologic units: $\mathrm{I}$ = clayey mud and foraminifer-bearing clayey mud, II = clayey mud, IIIA = clayey mud, diatom mud, silty and clayey diatom-bearing mud, IIIB = muddy diatom-nannofossil ooze and diatom clay, IIIC = clayey mud, diatom mud, silty and clayey diatom-bearing mud. 


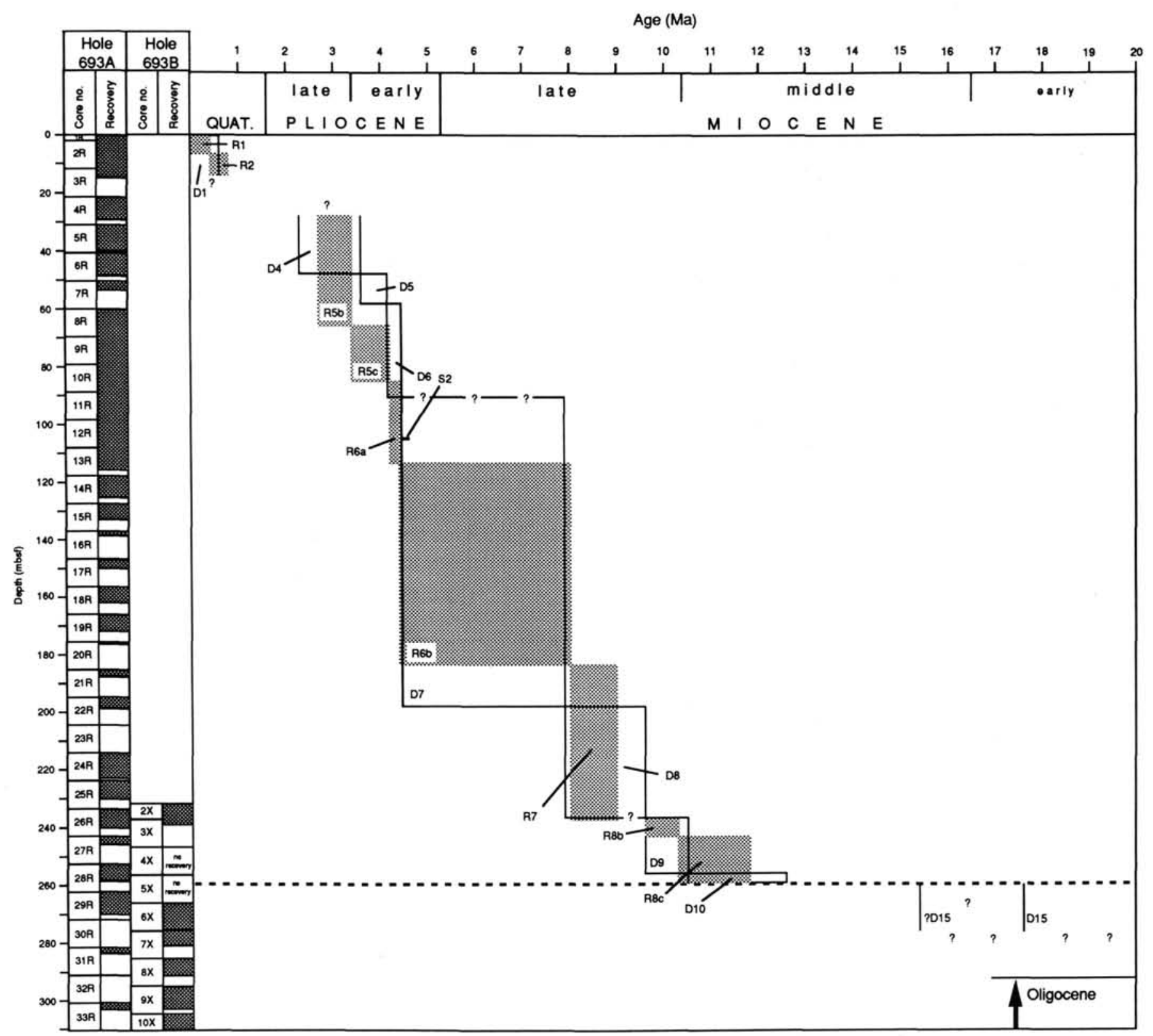

Figure 8. Age-depth interpretation of Holes 693A and 693B based on biosiliceous zonations. Boxes indicate depth/age range of radiolarian (R) zones (stippled boxes) and diatom (D) zones (open boxes). Bar S2 indicates depth and age range of top of "pseudofibula plexus" silicoflagellate Zone. Horizontal dashed line indicates location of hiatus. Explanation of diatom zonal numbers: D1. Thalassiosira lentiginosa Zone; D4. Nitzschia interfrigidaria/Cosmiodiscus insignis Zone; D5. Nitzschia barronii Zone; D6. Thalassiosira inura Zone; D7. Cosmiodiscus intersectus Zone; D8. Asteromphalus kennettii Zone; D9. Nitzschia praecurta Zone; D10. Denticulopsis praedimorpha Zone; D15. Nitzschia maleinterpretaria Zone. Radiolarian zonal numbers: R1. Omega Zone; R2. Psi Zone; R5b. middle Upsilon Zone; R5c. lower Upsilon Zone; R6a. upper Tau Zone; R6b. lower Tau Zone; R7. Acrosphaera australis Zone; R8b. middle C. spongothorax Zone; R8c. lower C. spongothorax Zone. For zonal definition see Tables 1 , 2 , and 3.

ary falls somewhere between Cores 113-696B-19R and 113696B-7R (221.5-134.5 mbsf). Whether this boundary is marked by a hiatus, as recorded at Sites 689,690 , and 695 , is not clear. However, at 150 mbsf, thus in the upper portion of the interval that must include the Miocene/Pliocene boundary, a strong seismic reflector occurs. This reflector is probably equivalent to the reflector at the Miocene/Pliocene of Site 695, and thus may probably indicate a disconformity between the Miocene and Pliocene at Site 696.

The sampled Miocene is rich in biosiliceous components, especially in diatoms. Average sedimentation rates for the late Miocene were estimated to be $35 \mathrm{~m} / \mathrm{m}$.y. This rate increases to ca.
$120 \mathrm{~m} / \mathrm{m} . \mathrm{y}$. during the middle Miocene, according to diatom biostratigraphic studies (Fig. 14, Table 4). The middle/upper Miocene boundary can be placed approximately between Cores 113-696B-26R and -25R, at ca. 290 mbsf (Gersonde and Burckle, this volume, chapter 43). Based on the pattern of the sedimentation rate curve (Fig. 14), it can be supposed that the middle/late Miocene boundary interval is marked by a hiatus that omits the upper portion of the Denticuloposis praedimorpha Zone. A prominent middle/late Miocene hiatus was also determined at Sites 689 and 690. Below Core 113-696B-50R (early middle Miocene $N$. grossepunctata Zone), no datable Neogene samples were obtained. For this reason the placement of the Oli- 


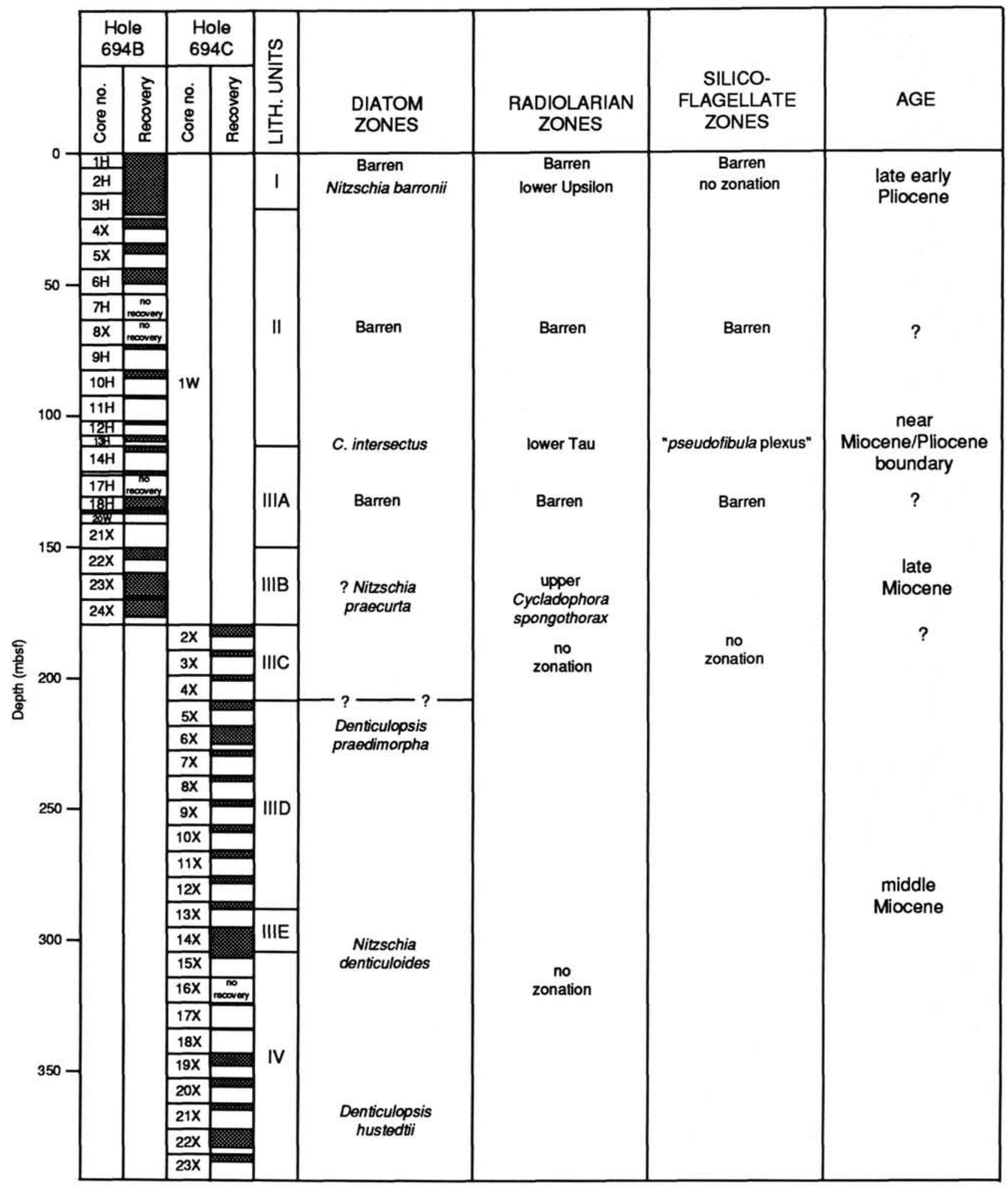

Figure 9. Summary of Neogene siliceous microfossil biostratigraphy, Holes 694B, C (central Weddell basin). Explanation of lithologic units: $\mathrm{I}=$ hemipelagic muds, fine-grained turbidites, II = coarse to fine sands, IIIA = muds, graded silts, sands, few diatoms, IIIB = diatombearing clayey mud, graded silts, IIIC = barren muds, silts, coarse sands, IIID = diatom-bearing muds, silts, sands, IIIE = gravel-bearing sandy and silty mud, IV = diatom and diatom-bearing claystones, silts near base. 


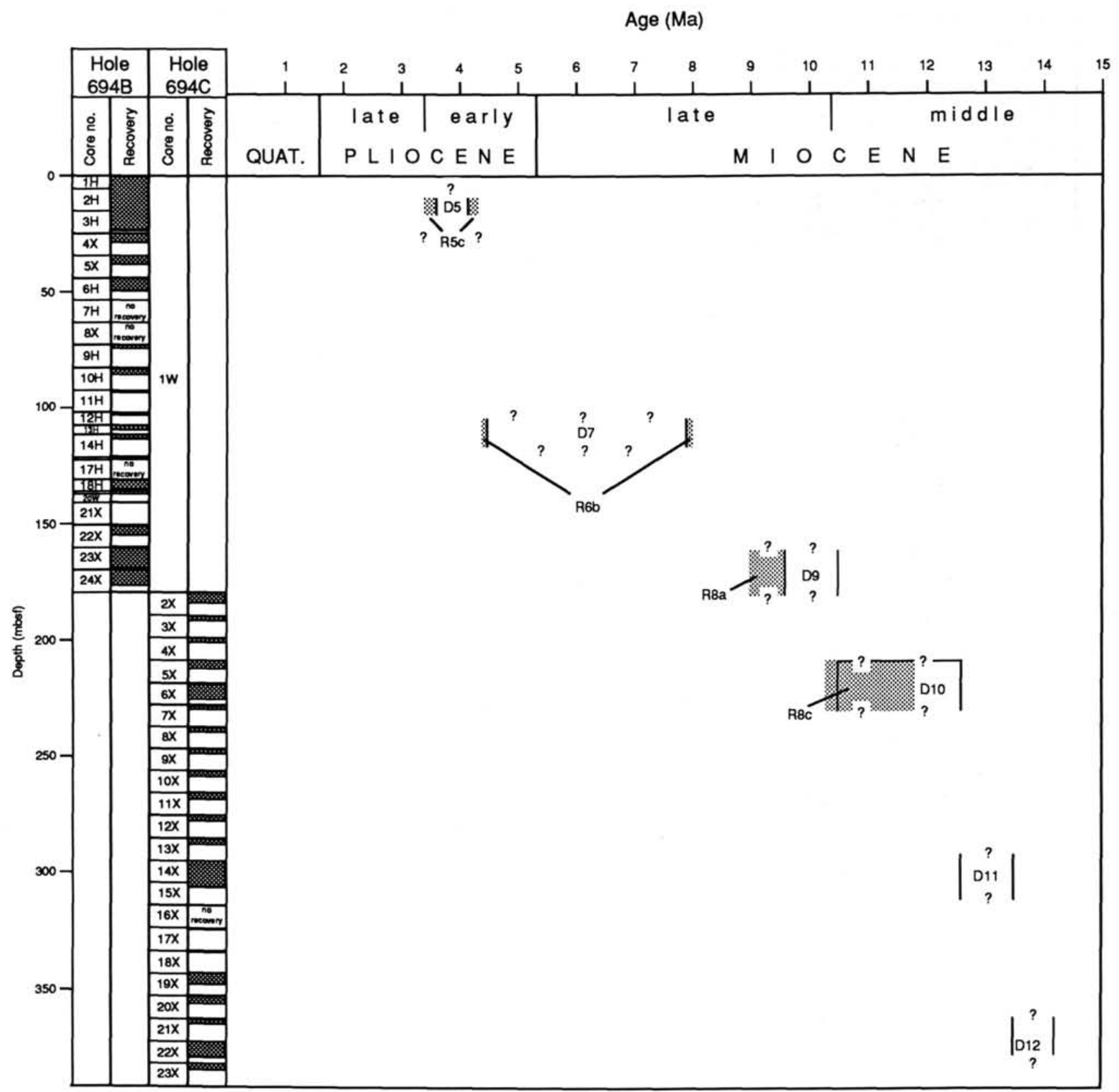

Figure 10. Age-depth interpretation of Holes 694B and 694C based on biosiliceous zonations. Boxes indicate depth/age range of radiolarian (R) zones (stippled boxes) and diatom (D) zones (open boxes). Explanation of diatom zonal numbers: D5. Nitzschia barronii Zone; D7. Cosmiodiscus intersectus Zone; D9. Nitzschia praecurta Zone; D10. Denticulopsis praedimorpha Zone; D11. Nitzschia denticuloides Zone; D12. Denticulopsis hustedtii/Nitzschia grossepunctata Zone. Radiolarian zonal numbers: R5c. lower Upsilon Zone; R6b. lower Tau Zone; R8a. upper C. spongothorax Zone; R8c. lower C. spongothorax Zone. For zonal definition see Tables 1 and 2.

gocene/Neogene boundary can only be estimated. The highest occurrence of microfossils indicating a Paleogene age was a calcareous nannofossil assemblage from Section 113-696B-59R, CC.

\section{SITE 697}

Site 697 lies in the Jane Basin $\left(61^{\circ} 48.6^{\prime} \mathrm{S}, 40^{\circ} 17.3^{\prime} \mathrm{W}\right)$ in $3480 \mathrm{~m}$ of water and is the deepest of the three-site transect on the southeast margin of the South Orkney microcontinent (SOM) in the northeast Weddell Sea (Fig. 1). Two holes were drilled at Site 697. Hole 697A recovered $26.6 \mathrm{~m}$ sediments of late Quaternary age in three APC cores and was then abandoned for technical reasons. Hole $697 \mathrm{~B}$ was washed to $18 \mathrm{mbsf}$ and cored to
322.9 mbsf using the APC and XCB techniques. A Quaternary to lower Pliocene sediment sequence was sampled in this hole (Fig. 15). Core recovery varies from good to moderate in the Quaternary through upper Pliocene, and from moderate to poor in the lower Pliocene. The recovered sediment sequences allowed the establishment of a magnetostratigraphic record for the calibration of Plio/Pleistocene biostratigraphic zonations. However, the abundance and preservation of siliceous microfossils exhibit strong fluctuations, thus some species ranges and zonal boundaries cannot be determined accurately.

In contrast to the other sites drilled during Leg 113 the Quaternary sediment sequence at Site 697 is expanded, and the aver- 


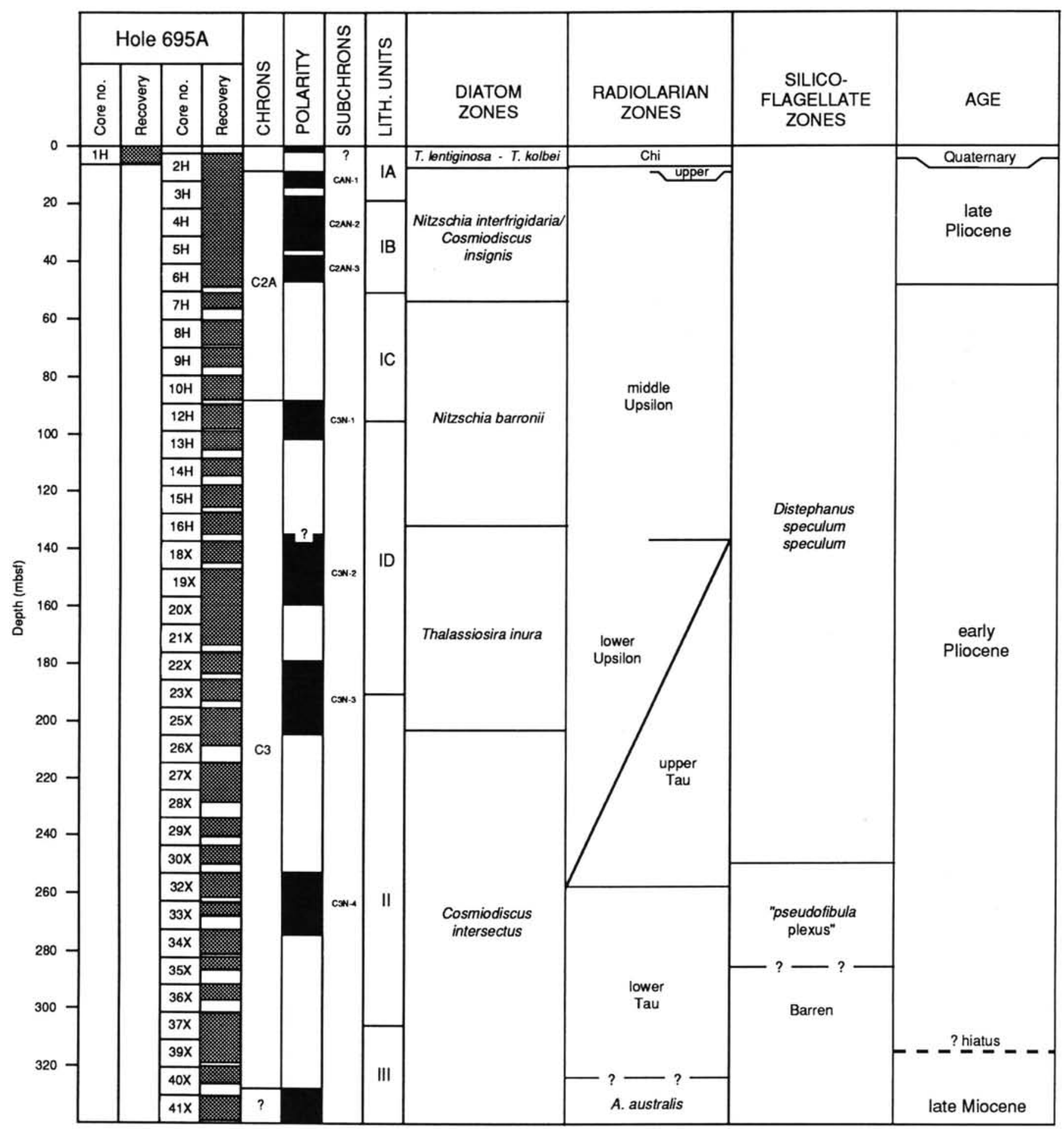

Figure 11. Summary of Neogene siliceous microfossil biostratigraphy, Hole 695A (southeast South Orkney microcontinent) correlated to the geomagnetic polarity pattern, according to Hamilton and O'Brien (unpublished data). Explanation of lithologic units: IA = diatom-bearing silty and clayey mud, IB = muddy diatom ooze and diatom-bearing silty mud, IC = silty and muddy diatom ooze, ID = muddy diatom ooze, diatom silty mud and diatom ooze, II = diatom-bearing silty and clayey mud, III = silty mud.

age sedimentation rate is ca. $28 \mathrm{~m} / \mathrm{m}$.y. (Fig. 16, Table 4). The same rate was also determined for the late Pliocene time interval. The Quaternary/Pliocene boundary can be placed between Cores 113-697B-5H and -6H and the upper Pliocene/lower Pliocene boundary is in Core 113-697B-16X. As it was recorded at other Leg 113 sites, the sedimentation rate increases (ca. $100 \mathrm{~m} /$ m.y.) during the early Pliocene. According to the biostrati- graphic and magnetostratigraphic results the base of Hole 697B is in the lowermost Pliocene (below Subchron C $3 \mathrm{~N}-4$ of Chron C3).

\section{SUMMARY}

During the first leg of the Ocean Drilling Program to the Southern Ocean, sediment sequences were recovered in the Wed- 


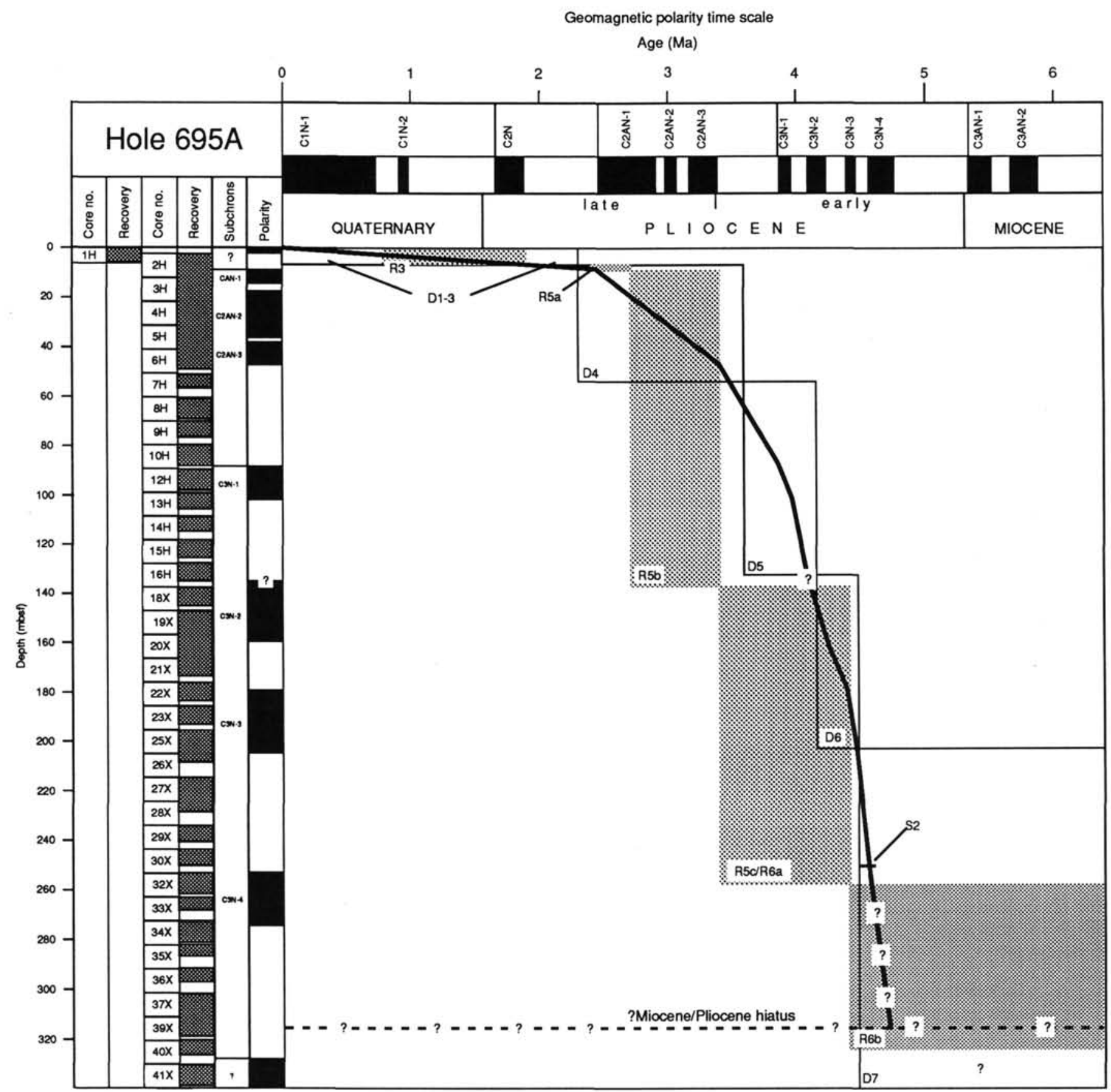

Figure 12. Age-depth interpretation of Hole 695A based on the geomagnetic polarity pattern (thick line) and biosiliceous zonations. Boxes indicate depth/age range of radiolarian (R) zones (stippled boxes) diatom (D) zones (open boxes). Bar S2 indicates depth and age range of top of "pseudofibula plexus" silicoflagellate Zone. Horizontal dashed line indicates location of probable Miocene/Pliocene hiatus. Explanation of diatom zonal numbers: D1. Thalassiosira lentiginosa Zone; D2. Actinocyclus ingens Zone; D3. Thalassiosira kolbei Zone; D4. Nitzschia interfrigidaria/Cosmiodiscus insignis Zone; D5. Nitzschia barronii Zone; D6. Thalassiosira inura Zone; D7. Cosmiodiscus intersectus Zone. Radiolarian zonal numbers: R3. Chi Zone; R5a. upper Upsilon Zone; R5b. middle Upsilon Zone; R5c. lower Upsilon Zone; R6a. upper Tau Zone; R6b. lower Tau Zone. For zonal definition see Tables 1, 2, and 3.

dell Sea (Atlantic sector) that allow the establishment of an improved and revised Neogene biostratigraphic zonation based on siliceous microfossils (diatoms, radiolarians, silicoflagellates) for the Neogene of the Antarctic Ocean. Continuous geomagnetic measurements on APC/XCB-drilled Neogene and Quaternary sections of Holes 689B, 690B, and 695A allowed for the first time a direct calibration of lowermost Pliocene and Miocene Antarctic biostratigraphic zones to the geomagnetic time scale. Most important for the establishment of the integrated bio- and magnetostratigraphy were Holes 689B and 690B, located on Maud Rise, despite the relatively low sedimentation rates of the pelagic sediments recovered at these sites, which range between $2.5 \mathrm{~m} / \mathrm{m}$.y. (lower Miocene interval) and $10.5 \mathrm{~m} /$ m.y. (lower Pliocene sections) (Table 4).

In general the Quaternary sequences of sites located in shallow water depths (Sites 689, 690, 693, 695, 696) bear biogenic 


\section{R. GERSONDE ET AL.}



Figure 13. Summary of Neogene siliceous microfossil biostratigraphy, Holes 696A, B (southeast South Orkney microcontinent). Striped boxes indicate range of uncertain age assignment for zonal boundaries. Explanation of lithologic units: $1 \mathrm{~A}=$ diatom-bearing silty mud, IB = diatom clayey mud and muddy diatom ooze, II = diatom-bearing silty mud and diatombearing clayey mud, III = silty and clayey mud and diatom-bearing clayey mud, IV = diatom ooze and muddy diatom ooze, $\mathrm{V}=$ coarse sand, VIA = diatom ooze and mud-bearing diatom ooze, VIB = mud-bearing diatomite and diatomite, $\mathrm{VIIA}=$ sandy mudstone. 


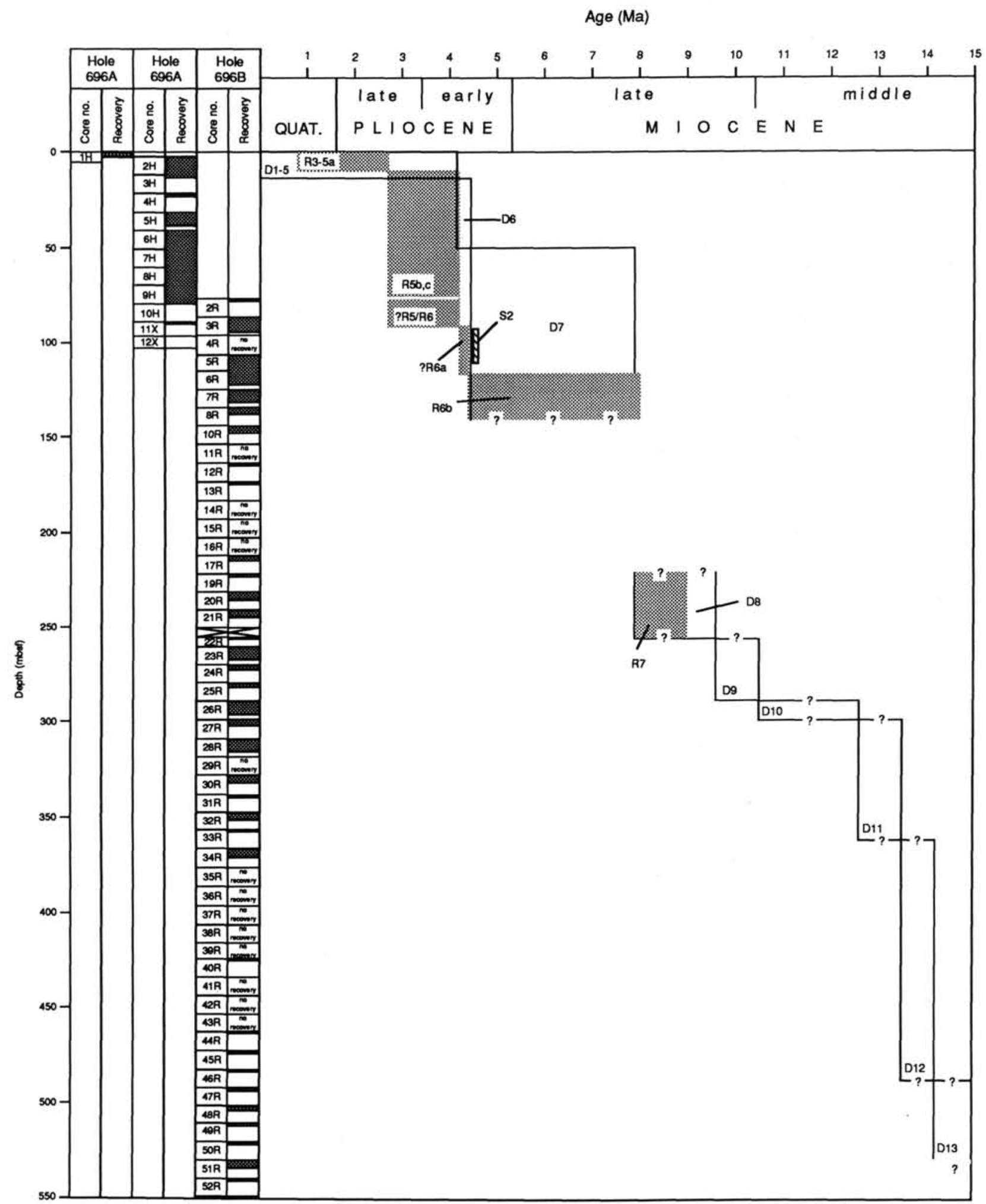

Figure 14. Age-depth interpretation of Holes 696A and 696B based on the biosiliceous zonations. Boxes indicate depth/age range of radiolarian (R) zones (stippled boxes), diatom (D) zones (open boxes), and a silicoflagellate (S) datum (striped box). Explanation of diatom zonal numbers: D1-5. Thalassiosira lentiginosa Zone-Nitzschia barronii Zone; D6. Thalassiosira inura Zone; D7. Cosmiodiscus intersectus Zone; D8. Asteromphalus kennettii Zone; D9. Nitzschia praecurta Zone; D10. Denticulopsis praedimorpha Zone; D11. Nitzschia denticuloides Zone; D12. Denticulopsis hustedtii/Nitzschia grossepunctata Zone; D13. Nitzschia grossepunctata Zone. Radiolarian zonal numbers: R3-5a. Chi Zone-upper Upsilon Zone; R5b. middle Upsilon Zone; R5c. lower Upsilon Zone; R6a. upper Tau Zone; R6b. lower Tau Zone. R6a. upper Tau Zone; R7. Acrosphaera australis Zone. Silicoflagellate datum: S2. top of "pseudofibula plexus" Zone. For zonal definition see Tables 1, 2, and 3. 




Figure 15. Summary of Neogene siliceous microfossil biostratigraphy, Holes 697A, B (southeast South Orkney microcontinent) correlated to the geomagnetic polarity pattern, according to Hamilton and O'Brien (unpublished data). Explanation of lithologic units: $1 \mathrm{~A}=$ silty mud and diatom-bearing silty mud, IB = clayey mud and clay, IC = diatom-bearing clayey mud, II = silty mud and clayey mud with ice-rafted detritus.

calcareous components consisting mostly of planktonic foraminifers. At the Maud Rise they consist of a foraminiferal ooze. The underlying Pliocene sediments are dominated by diatomaceous sediments. However, Quaternary and upper Pliocene sediments are in general condensed or marked by disconformities, except at Site 697 where the rates for this time interval are $28 \mathrm{~m} /$ m.y. on average. As recorded at the Maud Rise the highest sedimentation rates of all other studied Neogene sections occur in the early Pliocene. The highest rate of $170-250 \mathrm{~m} / \mathrm{m}$.y. on average was determined at Site 695 (Table 4), located on the southeast margin of the South Orkney microcontinent (Fig. 1). The high lower Pliocene sedimentation rates are due to increased biosiliceous accumulation in the upper and middle portion of the early Pliocene, whereas in the lower part of the early Pliocene the input of terrigenous sediments is strongly increased, except in the pelagic sequences drilled on Maud Rise. In general 


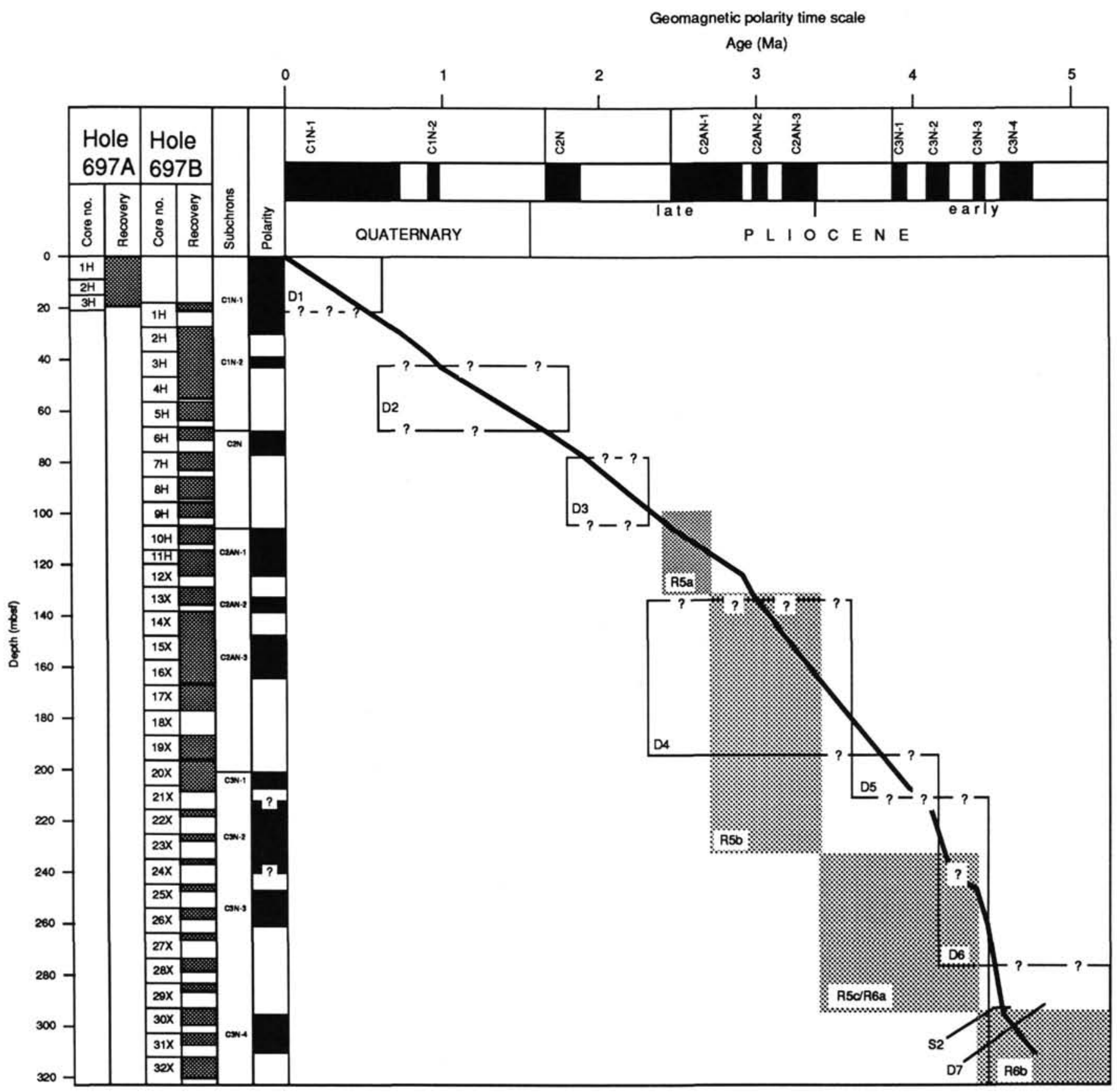

Figure 16. Age-depth interpretation of Holes 697A and 697B based on the geomagnetic polarity pattern (thick line) and biosiliceous zonations. Boxes indicate depth/age range of radiolarian (R) zones (stippled boxes) and diatom (D) zones (open boxes). Bar S2 indicates depth and age range of top of "pseudofibula plexus" silicoflagellate Zone. Explanation of diatom zonal numbers: D1. Thalassiosira lentiginosa Zone; D2. Actinocyclus ingens Zone; D3. Thalassiosira kolbei Zone; D4. Nitzschia interfrigidaria/Cosmiodiscus insignis Zone; D5. Nitzschia barronii Zone; D6. Thalassiosira inura Zone; D7. Cosmiodiscus intersectus Zone. Radiolarian zonal numbers: R5a. upper Upsilon Zone; R5b. middle Upsilon Zone; R5c. lower Upsilon Zone; R6a. upper Tau Zone; R6b. lower Tau Zone. For zonal definition see Tables 1, 2, and 3.

sediment accumulation declined during the late Miocene. At Sites 694 and 696 the middle Miocene rates are strongly increased.

Major hiatuses were determined at the Miocene/Oligocene boundary (Sites 689,690), at the early/middle Miocene boundary (Sites 689, 690), near or at the middle/late Miocene boundary (Sites 689, 690, 693, ?696) and at the Miocene/Pliocene boundary (Sites 689, 690, 695, ?696). The occurrence of these hiatuses is not restricted to the Weddell Sea region but corresponds to deep-sea hiatuses reported from Deep Sea Drilling Program and ODP sites located widespread in the Indian, Atlantic, Pacific, and Southern Oceans (Keller and Barron, 1987; Baldauf and Barron, in press). These disconformities can be related to major paleoceanographic events caused by tectonic processes (e.g., opening of deep Drake passage) or changes in paleoclimate. 


\section{ACKNOWLEDGMENTS}

The authors are grateful to John A. Barron and Annika Sanfilippo for critical review of the manuscript and many suggestions. This work was supported by the Deutsche Forschungsgemeinschaft. This is Alfred-Wegener-Institute contribution No. 217.

\section{REFERENCES}

Abelmann, A., Gersonde, R., and Spiess, V., in press. Pliocene-Pleistocene paleoceanography in the Weddell Sea-Siliceous microfossils evidence. In Bleil, U., and Thiede, J. (Eds.), Geological History of the Polar Oceans: Arctic Versus Antarctic, NATO/ASI Ser. C, Elsevier Acad. Publ.

Baldauf, J. G., and Barron, J. A., in press. Diatom biostratigraphy: Kerguelen-Plateau and Prydz Bay regions of the Southern Ocean. In Barron, J. A., Larsen, B., et al., Proc. ODP, Init. Repts., 119: College Station, TX (Ocean Drilling Program).

Barker, P. F., Kennett, J. P., et al., 1988. Proc. ODP, Init. Repts., 113: College Station, TX (Ocean Drilling Program).

Barron, J. A., 1985. Miocene to Holocene planktic diatoms. In Bolli, H. M., Saunders, J. B., and Perch-Nielsen, K. (Eds.), Plankton Stratigraphy: Cambridge (Cambridge Univ. Press), 763-809.

Berggren, W. A., Kent, D. V., and Van Couvering, J. A., 1985. The Neogene: Part 2, Neogene geochronology and chronostratigraphy. In Snelling, N. J. (Ed.), Geochronology of the geological record. Geol. Soc. Mem. 10:211-260.

Bukry, D., 1975. Silicoflagellate and coccolith stratigraphy, Deep Sea Drilling Project, Leg 29. In Kennett, J. P., Houtz, R. E., et al., Init. Repts. DSDP, 29: Washington (U.S. Govt. Printing Office), 845-872.

Chen, H., 1975. Antarctic Radiolaria. In Hayes, D. E., Frakes, L. A., et al., Init. Repts. DSDP, 28: Washington (U.S. Govt. Printing Office), 437-514.

Ciesielski, P. F., 1975. Biostratigraphy and paleoecology of Neogene and Oligocene silicoflagellates from cores recovered during Antarctic Leg 28, Deep Sea Drilling Project. In Hayes, D. E., Frakes,
L. A., et al., Init. Repts. DSDP, 28: Washington (U.S. Govt. Printing Office), 625-691.

Hays, J. D., 1965. Radiolaria and late Tertiary and Quaternary history of Antarctic seas. Am. Geophys. Un., Antarct. Res. Ser., 5:125184.

Hays, J. D., and Opdyke, N. D., 1967. Antarctic Radiolaria, magnetic reversals and climatic change. Science, 158:1001-1011.

Keany, J., 1979. Early Pliocene radiolarian taxonomy and biostratigraphy in the Antarctic region. Micropaleontology, 25:50-74.

Keller, G., and Barron, J. A., 1987. Paleodepth distribution of Neogene deep-sea hiatuses. Paleoceanography, 2:697-713.

McCollum, P. W., 1975. Diatom stratigraphy of the Southern Ocean. In Hayes, D. E., Frakes, L. A., et al., Init. Repts. DSDP, 28: Washington (U.S. Govt. Printing Office), 515-571.

Schrader, H. J., 1976. Cenozoic planktonic diatom biostratigraphy of the Southern Pacific Ocean. In Hollister, C. D., Craddock, C., et al., Init. Repts. DSDP, 35: Washington (U.S. Govt. Printing Office), 605-671.

Tauxe, L., Tucker, P., Petersen, N. P., and LaBreque, J. L., 1984. Magnetostratigraphy of Leg 73 sediments. In Hsü, K. J., LaBreque, J. L., et al., Init. Repts. DSDP, 73: Washington (U.S. Govt. Printing Office), 609-621.

Weaver, F. M., 1976. Antarctic radiolaria from the southeast Pacific Basin, DSDP Leg 35. In Hollister, C. D., Craddock, C., et al., Init. Repts. DSDP, 35: Washington (U.S. Govt. Printing Office), 569603.

1983. Cenozoic radiolarians from the southwest Atlantic, Falkland Plateau region, Deep Sea Drilling Project Leg 71. In Ludwig, W. J., Krasheninnikov, V. A., et al., Init. Repts. DSDP, 71: Washington (U.S. Govt. Printing Office), 667-686.

Weaver, F. M., and Gombos, A. M., 1981. Southern high-latitude diatom biostratigraphy. Soc. Econ. Paleontol. Mineral. Spec. Publ. 32: 445-470.

Date of initial receipt: 11 May 1989 Date of acceptance: 31 October 1989 Ms 113B-209 